\title{
The Biodiversity of the Genus Dictyota: Phytochemical and Pharmacological Natural Products Prospectives
}

\author{
Mohammed I. Rushdi ${ }^{1}$ (D), Iman A. M. Abdel-Rahman ${ }^{1}{ }^{\mathbb{D}}$, Eman Zekry Attia ${ }^{2} \mathbb{D}$, Hani Saber ${ }^{3}$, \\ Abdullah A. Saber ${ }^{4}\left(\right.$ D) Gerhard Bringmann ${ }^{5, *(D)}$ and Usama Ramadan Abdelmohsen $2,6, *$ (D)
}

1 Department of Pharmacognosy, Faculty of Pharmacy, South Valley University, Qena 83523, Egypt; mrushdy258@svu.edu.eg (M.I.R.); iman_abdelraheem@yahoo.com (I.A.M.A.-R.)

2 Department of Pharmacognosy, Faculty of Pharmacy, Minia University, Minia 61519, Egypt; eman_zekry@mu.edu.eg

3 Department of Botany and Microbiology, Faculty of Science, South Valley University, Qena 83523, Egypt; hani.saber@sci.svu.edu.eg

4 Botany Department, Faculty of Science, Ain Shams University, Abbassia Square, Cairo 11566, Egypt; abdullah_elattar@sci.asu.edu.eg

5 Institute of Organic Chemistry, University of Würzburg, Am Hubland, 97074 Würzburg, Germany

6 Department of Pharmacognosy, Faculty of Pharmacy, Deraya University, Universities Zone, New Minia 61111, Egypt

* Correspondence: bringman@chemie.uni-wuerzburg.de (G.B.); usama.ramadan@mu.edu.eg (U.R.A.); Tel.: +49-931-3185323 (G.B.); +20-86-2347759 (U.R.A.)

Citation: Rushdi, M.I.;

Abdel-Rahman, I.A.M.; Attia, E.Z.;

Saber, H.; Saber, A.A.; Bringmann, G.; Abdelmohsen, U.R. The Biodiversity of the Genus Dictyota: Phytochemical and Pharmacological Natural Products Prospectives. Molecules 2022, 27, 672. https://doi.org/ $10.3390 /$ molecules 27030672

Academic Editors: Enrique Barrajon, Vicente Micol and María Herranz-López

Received: 20 December 2021

Accepted: 19 January 2022

Published: 20 January 2022

Publisher's Note: MDPI stays neutral with regard to jurisdictional claims in published maps and institutional affiliations.

Copyright: (C) 2022 by the authors. Licensee MDPI, Basel, Switzerland. This article is an open access article distributed under the terms and conditions of the Creative Commons Attribution (CC BY) license (https:// creativecommons.org/licenses/by/ $4.0 /)$.

\begin{abstract}
Although a broad variety of classes of bioactive compounds have already been isolated from seaweeds of the genus Dictyota, most different species are still chemically and biologically unexplored. Dictyota species are well-known brown seaweeds belonging to the Dictyotaceae (Phaeophyta). The phytochemical composition within the genus Dictyota has recently received considerable interest, and a vast array of components, including diterpenes, sesquiterepenes, sterols, amino acids, as well as saturated and polyunsaturated fatty acids, have been characterized. The contribution of these valued metabolites to the biological potential, which includes anti-proliferative, anti-microbial, antiviral, antioxidant, anti-inflammatory, and anti-hyperpigmentation activities, of the genus Dictyota has also been explored. Therefore, this is the most comprehensive review, focusing on the published literature relevant to the chemically and pharmacologically diverse biopharmaceuticals isolated from different species of the genus Dictyota during the period from 1976 to now.
\end{abstract}

Keywords: Dictyota; Phaeophyceae; Dictyotaceae; marine macroalgae; brown seaweeds; natural products; bioactivities

\section{Introduction}

Marine natural products are characterized by the diversity of their chemical structures, displaying a wide spectrum of biological activities. The Red Sea is one of the most important marine hotspots comprising high seaweed biodiversity [1]. Several marine algae, particularly seaweeds, are biogeographically native to the Red Sea, but only a few species have been chemically examined during the past decades. Seaweeds have a growing number of successful applications in the food, medicine, and cosmetic industries, which increases the importance of evaluating their chemical composition [2]. Species of the genus Dictyota J.V. Lamouroux, as representatives of these seaweeds, are characterized by the following taxonomic features: flattened thalli, ribbon-like, erect or prostrate, with smooth dentate, crenulate, and ciliate margins; thallus attachment is fulfilled by means of uniseriate, multicellular branching, and hyaline rhizoids that may be divided terminally into fixing disk stoloniferous holdfasts, which may be present or absent; dichotomous orrarely falcate branching; obtuse, rounded, apiculate, or acute apices; Phaeophyceae hairs and superficial proliferations may be present or absent; the thallus differentiates into a cortex 
and a medulla, and the relative number of layers is variable; the scattered arrangement of sporangia throughout the thallus makes them easily separated from oogonia; the antheridia are prearranged in ellipse white sori. Ecologically, the genus Dictyota is primarily growing in tropical and subtropical marine waters on rocky reefs. In 1809, it was discovered by J.V. Lamouroux. So far, 222 different species are documented in the algae database; out of them, 98 species have been accepted taxonomically [3]. Dictyota is the richest genus of the family Dictyotaceae and produces a significant number of secondary metabolites, especially diterpenes. Many members of this family produce cyclic diterpenes, unique in the structural variety of marine natural products. The family Dictyotaceae has given rise to a great number of diterpenes generally grouped in three types: xenicanes, extended sesquiterpenes, and dolabellanes. One of the main seaweeds, named Dictyota dichotoma (Figure 1), grows on the coral reefs of Hurghada (the Red Sea, Egypt). The species D. dichotoma is the most widely distributed member of this family. It has been extensively studied, affording diterpenes of the three mentioned groups, although the studies have noted a wide range of variations among its constituents depending upon time and location of collection [4]. The genus Dictyota has recently gathered substantial attention from many researchers thanks to its economic significance during the past decade, represented in its potential as antibiofouling, animal feed, and pharmaceutical agents [5,6]. Some regions, including Hawaiian, Caribbean, and Malayan-Indonesian regions, locally consume Dictyota. Its application in the biofuel industry is attributed to its high contents of lipids and fatty acids [7]. Dictyota is also well known due to its high contents of sulfated polysaccharides such as fucans and fucoidans, which are responsible for great therapeutic applications such as immunomodulatory, antitumor, vaccine adjuvant, anti-inflammatory, antiprotozoal, nticoagulant, antiviral, antilipemic, and antimicrobial. It also plays a role in drug delivery and tissue engineering application [8]. Diterpenes have been of greater interest than other classes in literature survey; thus, Chen et al. reviewed diterpenes isolated from the genus Dictyota until 2018. Bogaert et al. produced an overview on the taxonomy, anatomy, cytology, genetic data, life history, chemical constituents, nutritional value as well as the economic and ecological significance of Dictyota species [7]. Accordingly, this review concentrates on the published literature relevant to the chemically and pharmacologically diverse biopharmaceuticals isolated from different species of the genus Dictyota during the period from 1976 to now.

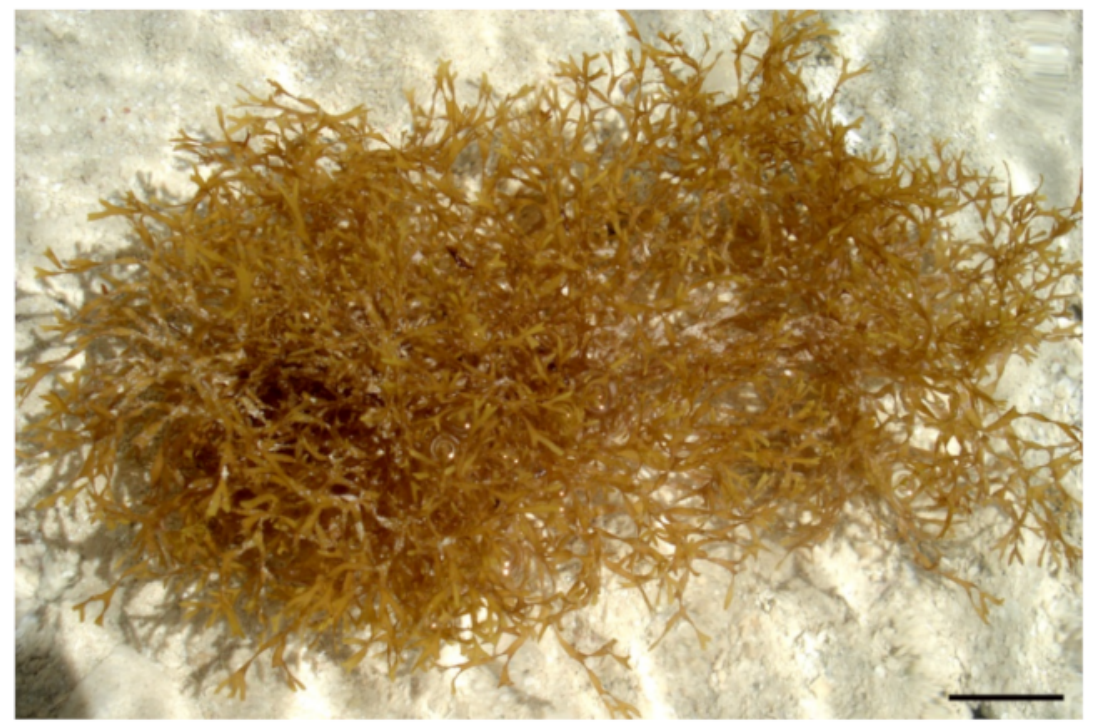

Figure 1. Dictyota dichotoma specimens from the Egyptian coastal water of Hurghada City, the Red Sea. Scale bar $=2 \mathrm{~cm}$. 


\section{The Pharmacological and Phytochemical Potential of the Genus Dictyota}

The current review concentrates on studies on the chemical composition of either isolated compounds or extracts and their bioactivities, whenever possible, afforded from different species of genus Dictyota [8,9].

\subsection{Dictyota acutiloba J. Agardh 1848}

Acutilol A (1), acutilol A acetate (2), and acutilol B (3) were detected in D. acutiloba, collected from Kauai (Hawaii) [10]. These acutilols diterpenes, compounds 1-3, are based on the common pachydictyane carbon skeleton but possess unusual $\Delta^{1,10}$ double bonds and act as potent agents against both temperate and tropical herbivorous fishes and sea urchins, suggesting that these molecules provide an effective chemical defense. Diterpenes likewise identified in D. acutiloba, yet collected from the Kahala and Ala Moana reefs (Hawaii), were the diterpenes dictyoxepin (4) and dictyolene (5) (Figure 2) [11]. The crude chloroform and crude acetone extracts of D. acutiloba from Rameswaram Island (India) were found to have anti-microbial activities against Bacillus subtilis, Salmonella typhi, Methicillin-resistant Staphylococcus aureus (MRSA), Staphylococcus aureus, Klebsiella pneumoniae, Pseudomonas aeruginosa, Enterobacter sp., Candida albicans, and Aspergillus niger (mean inhibition zone from $9 \pm 0.02$ to $23 \pm 0.031 \mathrm{~mm}$ ) and no antimicrobial activity was detected in crude methanolic or hexane extracts [12].

\subsection{Dictyota bartayresiana J.V. Lamouroux 1809}

9-Hydroxydolabelladien-6-one (6), 5-acetoxy-12-hydroxydolabell-3,7Z-dienone (7), 9acetoxydolabellatrien-16-al (8), 5-acetoxy-12-hydroxydolabell-3,7E-dienone (9), and trihydroxydolasta-2-en-6-one (10) (Figure 2) are diterpenes detected in D. bartayresiana, collected in the Gulf of Mannar of the Indian Ocean [13]. The antifungal effects of silver nanoparticles $(50 \mu \mathrm{L})$ were investigated, using an aqueous extract of brown seaweed D. bartayresiana collected from the Mandapam coastal region, Gulf of Mannar (India), against Mucor circinelloids and Fusarium dimerum (mean zone of inhibition: 19 and $12 \mathrm{~mm}$, respectively) [14]. Steroids, alkaloids, phenolic compounds, cardiac glycosides, flavonoids, saponins, tannins, and amino acids were identified in the phytochemical analysis of various extracts of $D$. bartayresiana, collected from Rasthacaud coastal waters, Kanyakumari District, Tamil Nadu, India. It was observed that the methanolic extract of $D$. bartayresiana expressed a maximum zone of inhibition against Escherichia coli $(9.4 \pm 0.2 \mathrm{~mm})$. A crude methanolic extract of $D$. bartayresiana showed the highest larval mortality (median lethal dose, $\mathrm{LC}_{50}=166.33 \mathrm{mg} / \mathrm{L}$ and $90 \%$ mortality $\mathrm{LC}_{90}=265.69 \mathrm{mg} / \mathrm{L}$ ) against Culex quinquefasciatus. Similarly, the methanolic extract of $D$. bartayresiana displayed the highest cytotoxicity, with $\mathrm{LC}_{50}$ and $\mathrm{LC}_{90}$ values of 202.63 and $354.24 \mathrm{mg} / \mathrm{L}$, respectively, against Artemia salina [15]. The antioxidant potential of the methanolic extract of D. bartayresiana J.V. Lamouroux (Phaeophyta), collected from the Mandapam coastal region of the Gulf of Mannar (southeast coast of India), was determined, for which the radical-scavenging 2,2-diphenyl-1picrylhydrazyl assay (DPPH), the ferric reducing antioxidant power assay (FRAP), and the superoxide-scavenging antioxidant capacity assay were performed. The methanolic extract of $D$. bartayresiana showed a DPPH radical-scavenging activity (the half maximal inhibitory concentration being $\left.\mathrm{IC}_{50}=8.2 \mu \mathrm{g} / \mathrm{mL}\right)$, an ascorbic acid equivalent $\left(\mathrm{IC}_{50}=3 \mu \mathrm{g} / \mathrm{mL}\right)$ and FRAP assay values of the extract, with ascorbic acid $\left(\mathrm{IC}_{50}=9.4\right.$ and $\left.5.6 \mu \mathrm{g} / \mathrm{mL}\right)$ as the reference standard. An eight-fold increase in scavenging superoxide radicals was observed; the $\mathrm{IC}_{50}$ value $(513.84 \mu \mathrm{g} / \mathrm{mL})$ was comparable with that of the reference standard quercetin $\left(\mathrm{IC}_{50}=67.8 \mu \mathrm{g} / \mathrm{mL}\right)$ [16]. The bio-synthesized $\mathrm{SiO}_{2}-\mathrm{ZnO}$ nanocomposites of $D$. bartayresiana, harvested from the Mandapam region (India), revealed promising potential against the HT29 cancer cell line, inhibited bacterial colonies of urinary tract infection pathogens, and showed promising antioxidant activity [17]. 


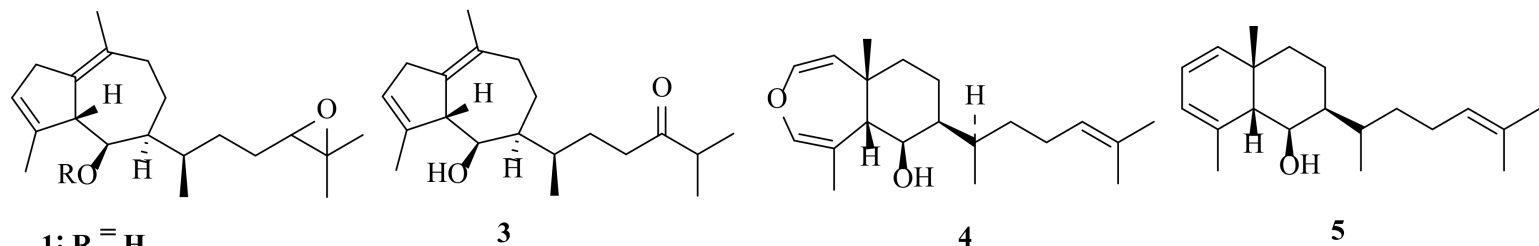

1: $\mathbf{R}=\mathbf{H}$

2: $R^{=} A^{c}$<smiles></smiles>

6<smiles>C=C1CC[C@H](C(C)C[C@H](C=C(C)C)OC(C)=O)C(O)[C@H]2C(C)=CC[C@H]12</smiles>

11<smiles>CC(=O)O[C@@H]1/C=C(\C)C(=O)CC2[C@](C)(C(C)C)CC[C@]2(C)C/C=C/1C</smiles><smiles>CC(=O)O[C@H]1C[C@@H]2C(C(C)C)=CC[C@H]2CC2=CCCC(C=O)=C21</smiles>

8<smiles>CC1=CCC[C@]2(C)CCC(O)[C@H]2CC(=O)/C(C)=C/C1</smiles>

9

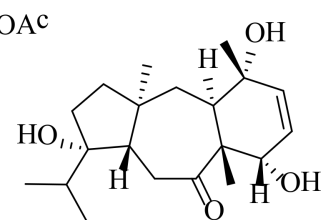

10<smiles>C=C1CC[C@H]2C(C)CCO[C@H]2[C@H]2C(C)=CC[C@@H]12</smiles>

12<smiles>C=C1[C@H](OC(C)=O)C[C@@H]([C@H](C)[C@@H](CC=C(C)C)OC(C)=O)[C@H](O)[C@]2(C)C(C)=CC[C@H]12</smiles>

13

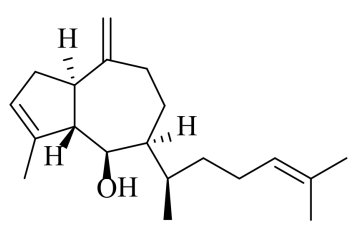

14<smiles>CC(C)=CCC[C@H](C)[C@H]1CC[C@@H]2O[C@H]1C1C(C)=CC[C@H]1C2C</smiles>

15<smiles>CO[C@H]1O[C@@H](OC)/C(=C/CC=C(C)C)[C@H]1C(C)CCC=C(C)C</smiles>

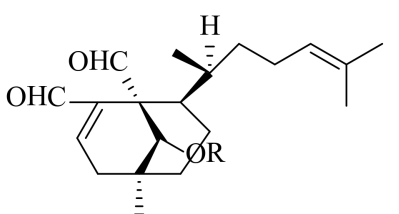

19: $R=H$

20: $R=A^{c}$<smiles>CC[C@H]1CCC=C([C@H](C)CCC=C(C)C)[C@@H](O)[C@@H]1O</smiles><smiles>C=C1CCC([C@]2(C)CC[C@@H](C(C)(C)OC(C)=O)O2)C(O)[C@H]2C(C)=CC[C@H]12</smiles><smiles>CC(C)=CCCC(C)C1CCC2C(C)CCC(C=O)C12C=O</smiles>

21

24<smiles>C=C1[C@H](OC(C)=O)C[C@@H](C(C)CCC=C(C)C)C(O)[C@]2(C)C(C)=CC[C@H]12</smiles>

17

18

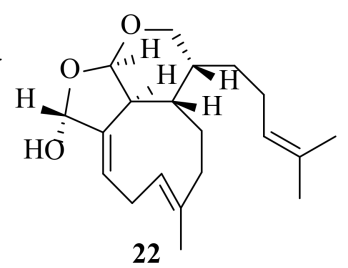<smiles></smiles>

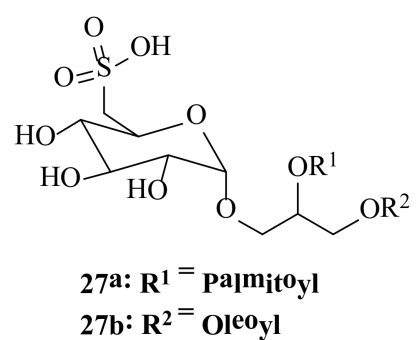

Figure 2. Chemical structures of compounds 1-27. Diterpenes 1-5 were isolated from D. acutiloba, diterpenes 6-10 were isolated from $D$. bartayresiana, diterpenes 11-16 were isolated from $D$. binghamiae, diterpenes 17-21 were isolated from $D$. caribaea, and diterpenes 22-26 and sulfonoglycolipid $\mathbf{2 7}$ were isolated from $D$. ciliolata. The configuration of all stereocenters in each compound is shown as given in the literature. 


\subsection{Dictyota binghamiae J. Agardh 1894}

Dictyol G acetate (11), dictyoxide A (12), dictyotriol A diacetate (13), pachydictyol A (14), dictyoxide (15), and dimethoxy dictyodial (16) (Figure 2) were detected in D. binghamiae, collected from Barkley Sound (British Columbia) [18].

\subsection{Dictyota caribaea Hörnig and Schnetter 1992}

The cytotoxic and anti-leishmanial activities of crude extracts of $D$. caribaea collected in the Gulf of Mexico and the Caribbean coast have been reported. The study revealed the presence of fucoidan, a humofucan with fucose as the neutral sugar. The sulfated polysaccharide-treated mice with 25 and $50 \mathrm{mg} / \mathrm{kg} /$ day depicted Sarcoma 180 tumor growth inhibition of $40 \%$ and $51 \%$, respectively, compared to negative control group. Sulfated polysaccharides treatment induced spleen weight increasing compared to the negative control group of $40 \%$ and $70 \%$ on mice treated with 25 and $50 \mathrm{mg} / \mathrm{kg} /$ day, respectively, along with intense white pulp disorganization. These results combined support an immunostimulant effect related to the in vivo antitumor effect of $D$. caribaea sulfated polysaccharides [19].

Sulfated polysaccharides isolated from D. caribaea, collected from Rio de Janeiro (Brazil), were tested for their antitumor effects. Antiproliferative activity of D. caribaea was tested against colon cancer (HCT 116) and metastatic melanoma (B16-F10) cell lines. The antitumor effect was evaluated on Swiss mice transplanted with sarcoma 180 tumor and treated by intraperitoneal injection during 7 days with saline or D. caribaea (25 and $50 \mathrm{mg} / \mathrm{kg}$ /animal). D. caribaea did not exhibit cytotoxicity in vitro, but mice treated with $D$. caribaea showed up to $50 \%$ tumor growth inhibition. D. caribaea treatment induced an increase in spleen weight, along with an intense white-pulp disorganization. Furthermore, D. caribaea did not exert hepatic toxicity, nephrotoxicity, or leukopenia, but it did induce an increase in platelets count [20]. The diterpenes pachydictyol A (14), isopachydictyol A (17), dictyol B acetate (18), dichotomanol (19), dichotomanol acetate (20), and cycloxenianol acetate (21) (Figure 2) were discovered in D. caribaea, collected from the Caribbean coast $[21,22]$.

\subsection{Dictyota ciliolata Sonder ex Kützing 1859}

Ciliolatale (22), 17-acetoxydictyodial (23), dictyol C (24), dictyol H (25), and dictyodial (26) (Figure 2) were detected in D. ciliolata, collected from Oualidia Lagoon (Morocco). Of these, 17-acetoxydictyodial (23) displayed mild antifungal activity against C. albicans ( $\mathrm{MIC}=50 \mathrm{mg} / \mathrm{mL})$ [23]. The sulfonoglycolipid 3-O-(6'-deoxy- $6^{\prime}$-sulfo- $\alpha$-Dglucopyranosyl)-1-O-oleoyl-2-O-palmitoylglycerol (27) was found in $D$. ciliolata [24]. Pachydictyol A (14) and dictyol B acetate (18) were isolated from $D$. ciliolata, collected from the Caribbean coast of the Yucatan peninsula. Pachydictyol A (14) reduced activity against all cancer cell lines tested-the ubiquitous keratin-forming tumor (KB), human epidermoid carcinoma, (Hep-2), human breast cancer (MCF-7), and human cervical cancer ( $\mathrm{SiHa}$ whereas dictyol B acetate (18) showed cytotoxic activity only against Hep-2 (the 50\% cytotoxic concentration, $\mathrm{CC}_{50}$, varying between 14.8 and $41.2 \mathrm{mg} / \mathrm{mL}$ ) [25].

\subsection{Dictyota coriacea (Holmes) I.K. Wang, H.S. Kim and W.J. Lee 2004}

Dictyospiromide (28) is a spirosuccinimide alkaloid, discovered in $D$. coriacea from the coast of Nanji Island, Wenzhou, Zhejiang Province (China). It has antioxidant properties, associated with activation of the Nrf2/ARE signaling pathway [26]. 1,9-Dihydroxycrenulide (29), epiloliolide (30), and D-mannitol (31) (Figure 3) were isolated from the ethanolic extract of $D$. coriacea, collected from the coasts of Jeju Island (Korea). The melanin synthesis inhibition activities were evaluated using B16F10 melanoma cells for the isolates. Compared with the positive control, arbutin, 1,9-dihydroxycrenulide (29) and epiloliolide (30) (Figure 3) exhibited more potency for treating hyperpigmentation and effective components of whitening cosmetics, showing 27.8 and $22.6 \%$ inhibition activities, respectively, at a substrate concentration of $30 \mu \mathrm{g} / \mathrm{mL}$ [27]. 1,9-dihydroxycrenulide (29) and epiloliolide (30) 
isolated from $D$. coriacea extract caused an increase in the proliferation of dermal papilla cells (DPCs). When isolated rat vibrissa follicles were treated with 1,9-dihydroxycrenulide (29) and epiloliolide (30) for 21 days, the hair-fiber lengths for the vibrissa follicles increased. Several solvent fractions of $D$. coriacea were examined for the activity of $5 \alpha$-reductase, which converts testosterone to dihydrotestosterone (DHT), a main cause of androgenetic alopecia. The results revealed the significant decrease in $5 \alpha$-reductase activity they caused, while 1,9-dihydroxycrenulide (29) and epiloliolide (30) scarcely inhibited $5 \alpha$-reductase activity. In addition, the $D$. coriacea extract and several solvent fractions of $D$. coriacea extract could not act as a KATP channel opener, which could be a contributory factor in the effect on hair growth. D. coriacea extract and 1,9-dihydroxycrenulide (29) and epiloliolide (30), principals of D. coriacea, have the potential to treat alopecia via the proliferation of DPCs [28].

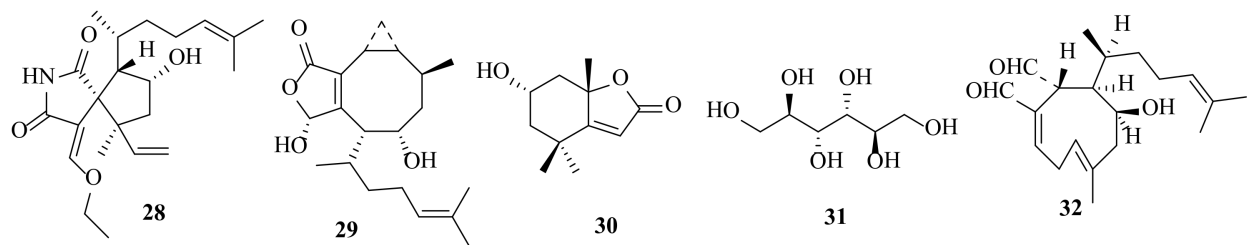

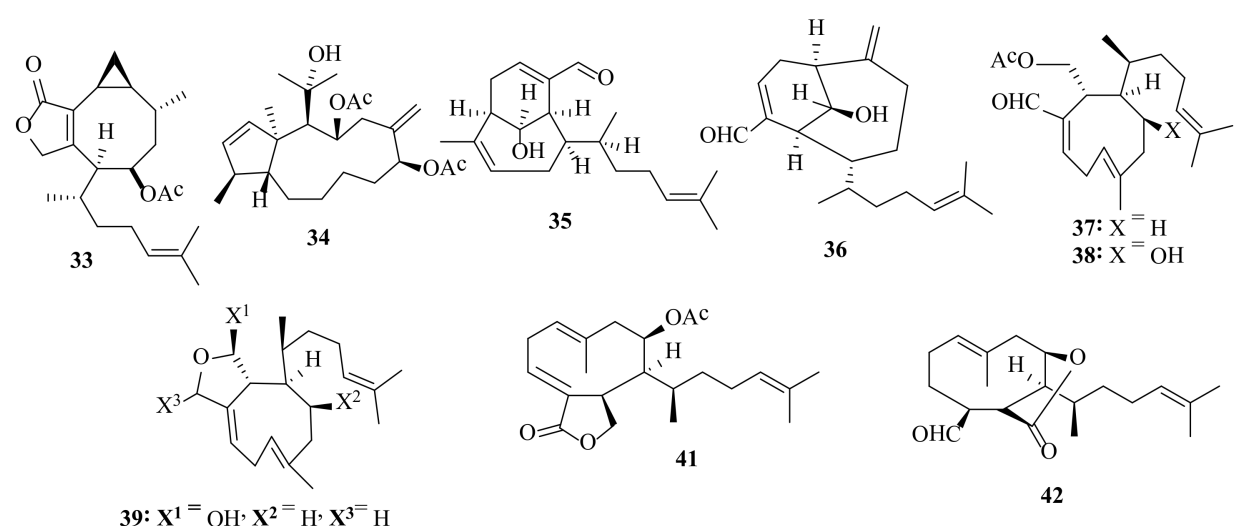

39: $\mathbf{X}^{1}={ }_{\mathrm{OH}}, \mathbf{X}^{2}={ }_{\mathrm{H}}, \mathbf{X}^{3}{ }^{=} \mathrm{H}$

40: $\mathbf{X}^{\mathbf{1}}=\mathrm{OCH}_{3}, \mathbf{X}^{\mathbf{2}}=\mathrm{OA}^{\mathrm{c}}, \mathbf{X}^{3}=\mathrm{OCH}_{3}$

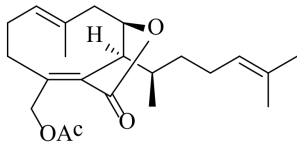

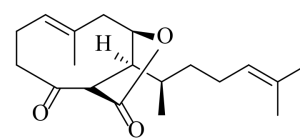<smiles>CC(C)=CCCC1CCC(C)c2ccc(C)cc21</smiles>

45

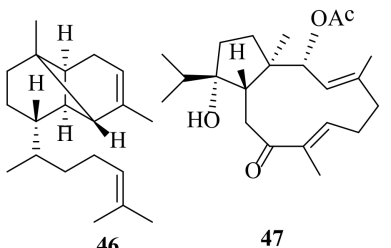<smiles>CC1=CCCC(C)(O)C[C@@]2(C)CC[C@@](O)(C(C)C)C1CC2=O</smiles>

48<smiles>C/C1=C\C[C@]2(C)CC[C@@H](C(C)C)C2CC(=O)C2(C)OC2CC1</smiles>

49<smiles>CC(=O)OC(C)/C(C)=C/CCC(C=O)/C=C/[C@@]1(C)CC=C(C(C)C)C1C</smiles>

50

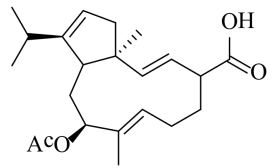

51

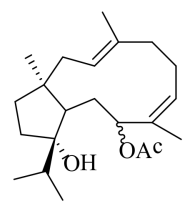

52<smiles>CC(=O)OC1CC(C)C2(C)OC2CCC(C)=CC[C@]1(C)CCC(C)C</smiles>

53<smiles>CCC1C[C@]2(C)CC[C@](O)(C(C)C)C2CC(=O)C1(C)C</smiles>

54<smiles>CC1=CCC[C@](C)(O)C=C[C@]2(C)CC[C@H](C(C)C)C1CC2=O</smiles>

55<smiles>CCC(=O)C(C)=CCCC(C)(O)C=C[C@@]1(C)CC[C@](O)(C(C)C)C1CC</smiles>

56

Figure 3. Chemical structures of compounds 28-56. The spirosuccinimide alkaloid 28, thediterpenes 29-30, and the sugar 31 were isolated from D. coriacea, the diterpenes 32-36 were isolated from $D$. crenulata, and the diterpenes $37-56$ were isolated from $D$. dichotoma. The configuration of all stereocenters in each compound is shown as given in the literature. 
The ethanolic extract, as well as the $n$-hexane and ethyl acetate fractions of $D$. coriacea, collected from the sea adjacent to Jeju Island, displayed a dependently inhibitory effect on tyrosinase activity and melanin content in B16F10 cells. The ethanolic extract and its fractions showed an inhibitory effect on tyrosinase and human tyrosinase-related protein-1 (TRP-1) gene transcription but did not exert an inhibitory effect on human tyrosinaserelated protein-2 (TRP-2) gene transcription. Moreover, the $n$-hexane and ethyl acetate fractions dose-dependently inhibited the production of NO in RAW 264.7 cells. These results suggest that the extract of $D$. coriacea could be used as a functional biomaterial in developing a skin-whitening agent that has anti-inflammatory activity [29].

\subsection{Dictyota crenulata J. Agardh 1847}

$4 \beta$-Hydroxydictyodial A (32) was detected in D. crenulata, collected at Kualoa Beach Park, Oahu, Hawaii [30]. A bicyclic cyclopropane-containing diterpenoid, named acetoxycrenulide (33), was found in D. crenulata, collected from the Gulf of California (Mexico). Dictyocrenulol (34) was identified in D. crenulata, collected from Hanga Roa (Chili) [31]. $\beta$-Crenulal (35) and sanadaol (36) (Figure 3) were discovered in D. crenulata, harvested from Japan [32]. Pachydictyol A (14), isopachydictyol A (17), dictyol C (24), dictyodial (26), $4 \beta$-hydroxydictyodial A (32), prenylated guaiane, and xenia diterpenes were isolated from the crude extract of the Brazilian D. crenulata [33]. Both (-)- and (+)-sanadaol (36) were synthesized stereoselectively from a chiral bicyclo[2.2.2]octane derivative prepared from D-mannitol [34].

\subsection{Dictyota dichotoma (Hudson) J.V. Lamouroux 1809}

D. dichotoma was the most valuable seaweed due to its relatively high protein content of $7.28 \pm 0.25 \%$, moderate carbohydrate content of $25.35 \pm 0.32 \%$, and highest pigment and antioxidant contents [35]. In D. dichotoma, collected from Peter the Great Bay, Sea of Japan (Russia), the dictyota D-glucan laminaran (DdL) and the dictyota D-glucan fucoidan (DdF) were detected. DdF is a sulfated (28.9\%) and acetylated heteropolysaccharide containing fucose, galactose, mannose, and glucose (57.9, 20.4, 12.4, and $9.2 \mathrm{~mol} \%$, respectively). Laminaran is a 1,3;1,6- $\beta$-D-glucan with the main chain built up from 1,3-linked D-glucose residues [36].

There can be 6-O-branches and $\beta-(1 \rightarrow 6)$ intrachain links in the main chain. Sulfated $(43.7 \%)$ laminaran DdLs were obtained from DdL by chemical sulfation.

The sulfates were found to occur at C2, C4, and C6 of the glucose residues. The anticancer effects of DdF, DdL, and DdLs $(200 \mu \mathrm{g} / \mathrm{mL})$ were measured in vitro on colon cancer cells (HCT-116, HT-29, and DLD-1). The effect of polysaccharides $(40 \mu \mathrm{g} / \mathrm{mL})$ on colony formation of DLD-1 cancer cells after irradiation was investigated. All polysaccharides showed a synergistic effect with $\mathrm{X}$-ray irradiation against cancer cells, decreasing the amount and size of cancer cell colonies [36].

The laminarans are neutral, water-soluble $\beta$-D-glucans possessing potent immunomodulating, radioprotective, and anticancer activities. The in vitro anticancer, radioprotective, and radiosensitizing activities of laminaran from $D$. dichotoma and its sulfated derivative were investigated. The native and sulfated laminarans by themselves at non-toxic doses possessed significant anticancer activity against melanoma cells. Both polysaccharides protected normal epidermal cells, while only sulfated laminaran was able to sensitize melanoma cells to X-ray irradiation, resulting in significant inhibition of cell proliferation, colony formation, and migration of cancer cells [37].

The molecular mechanism of this action was found to be related to the inhibition of matrix metalloproteinase-2 (MMP-2) and matrix metalloproteinase-9 (MMP-9) proteinases activity and to the down-regulation of kinases phosphorylation of the ERK1/2 signaling cascade [37].

The galactofucan-rich fractions, obtained from $D$. dichotoma thalli exhibited moderate inhibitory effects against Herpes simplex virus (HSV-1) and Coxsackie virus (CVB3) [38]. The ethanolic extract of $D$. dichotoma possessed active compounds for the development of larvi- 
cidal activity against 4 th instars larvae of the yellow-fever mosquito, Aedes aegypti. The extract of $D$. dichotoma revealed that the minimum level of an $\mathrm{LC}_{50}$ value was $0.0683 \pm 0.0084 \mu \mathrm{g} / \mathrm{mL}$.

The preliminary phytochemical constituents showed the presence of saponins, steroids, terpenoid, phenols, protein, and sugars [39]. Hexadecanoic acid, tetradecanoic acid, 2hydroxyhexadecanoic acid, palmitic acid, elaidic acid, stearic acid, cis-11,14,17-eicosatrienoic acid, and erucic acid were isolated from D. dichotoma, collected at Pulau Nunuyan Laut, Sandakan, Sabah, with the contents of the co-occurring poly- and mono-unsaturated fatty acids being higher than the saturated fatty ones [40].

Diacylglycerol hydroxymethyl trimethyl- $\beta$-alanine (DGTA), a recently identified betaine lipid [41], was found as a major lipid component in D. dichotoma, collected at the seashore near Tokyo, Japan. For the fatty acids of DGTA in D. dichotoma, the major components were palmitic acid 16:0, linoleic acid 18:2, and arachidonic acid 20:4w6 [41].

For $D$. dichotoma, collected from the Western seacoast of Yemen, anticancer and antioxidant activities were detected. The chloroform fraction of the $D$. dichotoma displayed the highest cytotoxic activity and was most effective against MCF-7, human prostate cancer cells (PC-3), and colorectal adenocarcinoma cells (CACO), $\left(\mathrm{IC}_{50}=1.93 \pm 0.25,2.2 \pm 0.18\right.$, and $2.71 \pm 0.53 \mu \mathrm{g} / \mathrm{mL}$, respectively). The petroleum ether fraction was also effective, particularly against MCF-7 and PC-3 $\left(\mathrm{IC}_{50}=4.77 \pm 0.51\right.$ and $3.93 \pm 0.51 \mu \mathrm{g} / \mathrm{mL}$, respectively), whereas the activity of the ethyl acetate fraction was more pronounced against HepG2 and $\mathrm{CACO}\left(\mathrm{IC}_{50}=5.06 \pm 0.21\right.$ and $5.06 \pm 0.23 \mu \mathrm{g} / \mathrm{mL}$, respectively $)$. Of all the extracts tested, the crude methanolic extract of the algae exhibited the best antioxidant potential $\left(\mathrm{IC}_{50}=204.6 \pm 8.3 \mu \mathrm{g} / \mathrm{mL}\right)$. Doses as high as $5000 \mathrm{mg} / \mathrm{kg}$ body weight of $D$. dichotoma methanolic extracts were safe and well tolerated by rats [42].

In D. dichotoma, collected from Oshoro Bay, Hokkaido, acetyldictyolal (37), hydroxyacetyldictyolal (38), isodictyohemiacetal (39), and dictydiacetal (40), i.e., cyclononane diterpenes were detected [43].

4-Acetoxydictyolactone (41), dictyotalide A (42), dictyotalide B (43), and nordictyotalide (44) were discovered in $D$. dichotoma, collected from the coast of Nakijin, Okinawa, with significant cytotoxic activity against B16 melanoma cells [44].

The diterpenes ent-erogorgiaene (45) and 1,5-cyclo-tetrahydroerogorgiaene (46) were identified in the Russian far-eastern population of D. dichotoma [45].

Acetoxy-hydroxy-dolabella-3,7-dien-9-one (47), 3,4-epoxy-hydroxy-dolabella-7-en9-one (48), 7,8-epoxy-hydroxy-dolabella-3-en-9-one (49), 9-acetoxydolabella-3,7,12-trien16-al (50), 9-acetoxydolabellatrien-16-oic acid (51), 9-acetoxydolabella-3,7-dien-12-ol (52), 9-acetoxy-7,8-epoxydolabella-3-en-12-ol (53), 9-hydroxydolest-1,3-dien-6-one (54), 4,12dihydroxydolabella-2,7Z-dien-9-one (55), 4,12-dihydroxydolabella-2,7E-dien-9-one (56) (Figure 3), 12-hydroxydolabella-3,7E-dien-9-one (57), 12-hydroxydolabella-3,7Z-dien-9-one (58), 4,12-dihydroxydolabellan-2,6-dien-9-one (59), 4,12-dihydroxydolabellan-2,6-dien-9one (60), 12Z-hydroxydolabella-3,6-dien-9-one (61), and 12E-hydroxydolabella-3,6-dien-9one (62) were found in D. dichotoma collected from the Indian Ocean [46].

Isopachydictyol A (17), 5,6,18-triacetoxy-hydroxy-dolabelladiene (63), 18-acetoxy-10hydroxy-2,7-dolabelladiene (64), 5-acetoxy-dihydroxy-2,7-dolabelladiene (65), 7,8-epoxy-3,18dolabelladiene (66), 18-acetoxy-2,7-dolabelladiene (67), and dictyotatriol A (68) (Figure 4) were found in $D$. dichotoma collected from the intertidal zone of Cortadura (Cadiz, Spain) [4]. 


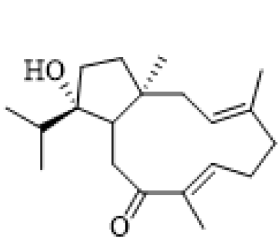

57

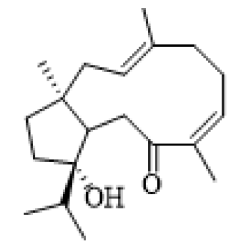

58

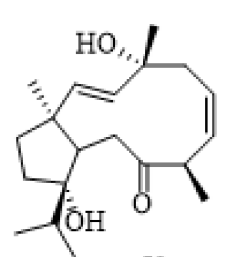

59<smiles>CC(C)C1CC[C@]2(C)/C=C/C(C)(O)C/C=C\[C@H](C)C(=O)CC12</smiles>

60

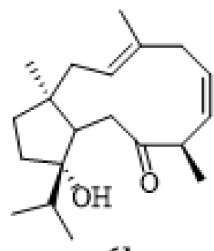

61

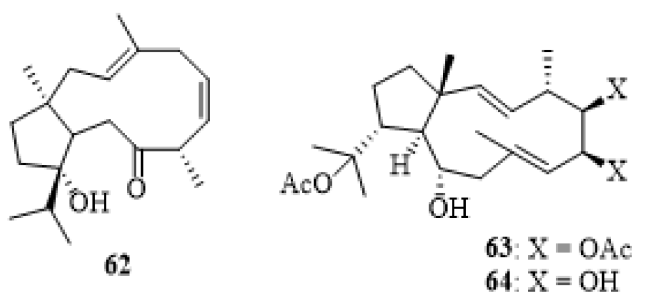<smiles>C=C1CCC(C(C)CCC=C(C)C)C(O)[C@]2(C)[C@@H](O)C[C@@H](O)[C@]12C</smiles>

$67 \cdot \mathrm{x}=\mathrm{H}$

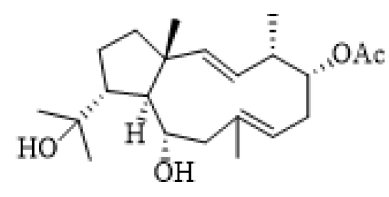

65<smiles>C=C(C)[C@H]1CCC2(C)CC[C@]34O[C@@H]3C[C@H](OC(C)=O)C(C)=C4CC[C@H]12</smiles>

66<smiles>[Z]C(C)[C@H]1CC[C@H](O)[C@@H]2CCC(C)=C[C@H]2[C@@H]1CCC=C(C)C</smiles>

69<smiles>COC[C@H]1CC[C@H](C(C)CCC=C(C)C)[C@H]2C=C(C)CC[C@H]12</smiles>

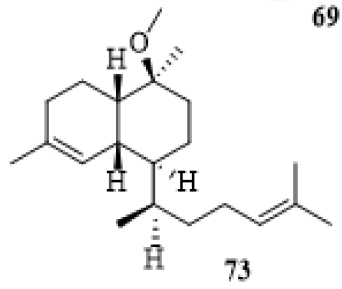<smiles>C=C1CC[C@H](C(C)CC[C@H](O)C(C)(C)Cl)C(O)[C@H]2C(C)=CC[C@H]12</smiles><smiles>CC(C)=CCC[C@@H]1[C@H](C)CC/C(C)=C\C/C=C2/C(=O)OC[C@@H]21</smiles><smiles>C=C1C(C(C)CCC=C(C)C)C(O)CC(C(C)CCC=C(C)C)C(O)[C@H]2C(C)=C(C)C[C@H]12</smiles>

76<smiles>C=C(C)C(O)CCC(C)[C@H]1CCC(=C)[C@H]2CC=C(C)[C@H]2[C@H]1O</smiles>

78<smiles>C=C1CC[C@H](C(C)CC[C@@H](O)C(=C)C)[C@H](O)[C@@H]2C(C)=CC[C@H]12</smiles><smiles>CO[C@H]1CC[C@@H](C(C)CCC=C(C)C)C[C@@H]2C(C)=CC[C@H]12</smiles>

80<smiles>C=C1CC[C@H](C(C)CCC2OC2(C)C)C(O)[C@H]2C(C)=CC[C@H]12</smiles>

81

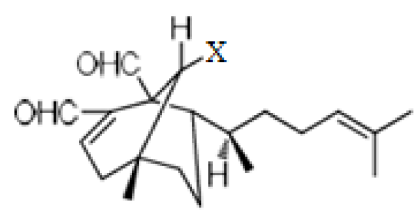

83: $\mathrm{X}=\mathrm{OH}$

84: $\mathrm{X}=\mathrm{OAC}$

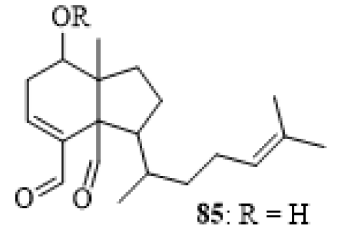

86: $\mathrm{R}=\mathrm{Ac}$

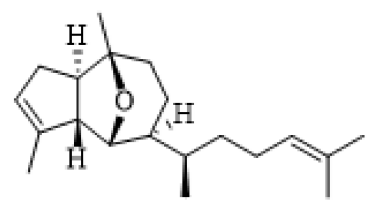

82<smiles>CO[C@H]1O[C@H](OC)C2=C1[C@H]1C[C@@H]1[C@H](C)C[C@@H](O)[C@@H]2C(C)CCC=C(C)C</smiles>

Figure 4. Chemical structures of compounds 57-87. The diterpenes 57-87 were isolated from D. dichotoma. The configuration of all stereocenters in each compound is shown as given in the literature.

Dictyotin A (69), dictyotin B (70), dictyotin C (71), methoxydictyldiene (72) and dictyotin D methyl ether (73) (Figure 4), were isolated from D. dichotoma collected in Yagachi, Okinawa [47]. The chlorine-containing perhydroazulene diterpene dictyol J (74), dictyolactone (75), and sanadaol (36) were identified in the ethanolic extract of $D$. dichotoma harvested 
in Japan. Dictyolactone (75) showed the highest algicidal activity against red-tide phytoplanktons. The isolated compounds 36 and $\mathbf{7 4 - 7 5}$ were assayed for their algicidal activity against the three representative harmful algal bloom (HAB) species, Heterosigma akashiwo, Karenia mikimotoi, and Alexandrium catenella. All these compounds showed high $(>95 \%)$ algicidal activity against $H$. akashiwo and K. mikimotoi at a dose of $10-20 \mathrm{mg} / \mathrm{mL}$, with dictyolactone (75) being the most active one. Interestingly, dictyolactone (75) also displayed moderate activity $(41.5 \pm 8.2 \%$ at $10 \mathrm{mg} / \mathrm{mL})$ against the dinoflagellate Alexandrium catenella, while the other compounds and the known algicidal agent $\alpha$-linolenic acid were totally inactive to this species [48]. Dictyol A (76) and dictyol B (77), two diterpene alcohols with a hydroazulene ring system, were detected in $D$. dichotoma collected from the Italian coast [49].

Dictyol F (78), epidictyol F (79), dihydromethoxy-pachydictyol A (80), 14,15-epoxypachydictyol A (81), and 2,6-cycloether pachydictyol A (82) were identified in the methanolic extract of $D$. dichotoma, harvested at Oshoro Bay, Hokkaido [50]. 9R-Hydroxydichotoma2,14-dien-19,20-diol (83), 9R-acetoxydichotoma-2,14-dien-19,20-diol (84), 7-hydroxy-2,6cycloxenicadien-18,19-diol (85), and 7-acetoxy-2,6-cycloxenicadien-18,19-diol (86) were discovered in the dichloromethane extract of the Australian D. dichotoma [51]. Likewise found in D. dichotoma were crenulacetal A (87) (Figure 4), crenulacetal B (88), crenulacetal $C$ (89), and crenulacetal D (90) [52]. The seco-dolastanes dichotone (91) and dichotodione (92) were isolated from $D$. dichotoma from Karachi (Pakistan) [53]. Dictyohydroperoxide (93), hydroperoxyacetoxycrenulide (94) (Figure 5), and the diterpenoid hydroperoxide acetoxycrenulide (33) were found in the Russian D. dichotoma [54].

Seco-fusicoccin-type diterpene dictymal (95) was detected in $D$. dichotoma, collected from Oshoro Bay, Hokkaido [55]. In D. dichotoma collected from the Karachi coast, the dolastane-diterpenoids, dichotenone A (96), dichotenone B (97), and loliolide (98) were identified (Figure 5) [56]. Dichotenol A (99), dichotenol B (100), and dichotenol C (101), all C-16 oxidized seco-dolastanes, were discovered in D. dichotoma, collected from the Karachi coast of the Arabian Sea [57]. Hydroazulenoid diterpenes, dictytriene A (102), dictytriene B (103), dictyone (104), and dictytriol (105) (Figure 5) were isolated from a Japanese D. dichotoma [58]. The tricarbocyclic cycropropanoid diterpenes tricyclodictyofuran A (106), tricyclodictyofuran B (107), and tricyclodictyofuran C (108) were detected in the methanolic extract of D. dichotoma, collected from Oshoro Bay, Hokkaido (Figure 5) [59].

Dictyoxetane (109) was isolated from $D$. dichotoma, collected from the Indian Ocean [60]. Pachydictyol B (110) and pachydictyol C (111) were isolated from the dichloromethane extract of $D$. dichotoma collected from the Red Sea coast of Egypt, along with the known metabolites, pachydictyol A (14), dictyol E (112), cis-africanan- $1 \alpha$-ol (113), fucosterol (114), tetrahydrothiophen-1,1-dioxide, and poly- $\beta$-hydroxybutyric acid. $\beta$-Bourbonene and nonanal, along with three hydrocarbons as well as five fatty acids and their simple derivatives were detected in the GC-MS analysis of the nonpolar fractions. GC-MS analysis of the unsaponifiable algal petroleum ether extract revealed the presence of eight further compounds, including 2,2,6,7-tetramethyl-10-oxatricyclo[4.3.0.1(1,7)]decan-5-one (115), $\mathrm{N}$ (4-bromo- $n$-butyl)-piperidin-2-one (116) and tert-hexadecanethiol (117) (Figure 5). The crude algal extract was potently active against the breast carcinoma tumor cell line, MCF7 $\left(\mathrm{IC}_{50}=0.6 \mu \mathrm{g} / \mathrm{mL}\right) ;$ pachydictyol B (110) and dictyol E (112) showed weak antimicrobial properties, while the other compounds were inactive. Pachydictyol B (110) and pachydictyol C (111) demonstrated a weak and unselective cytotoxicity against twelve human tumor cell lines with a mean $\mathrm{IC}_{50}$ of $>30.0 \mu \mathrm{M}$ [61]. Dictyol B acetate (18) and dictyotadiol (118) (Figure 5) are diterpenes from $D$. dichotoma [62]. 


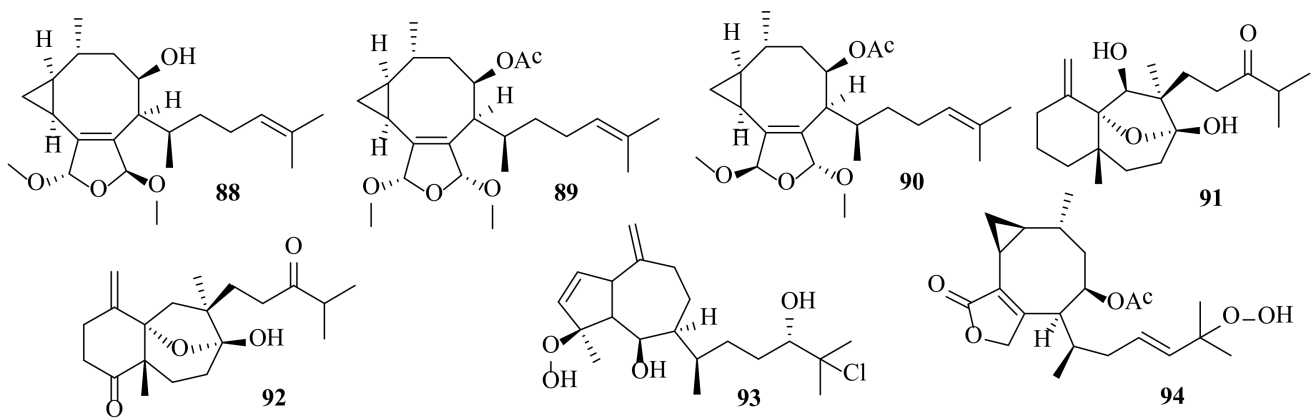

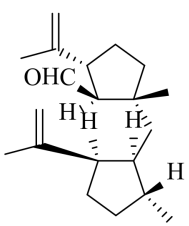

95

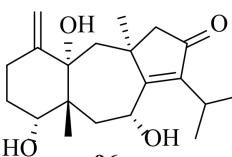<smiles>CCCCCCCCCCC(C)(C)O</smiles><smiles>C=C1CC=C([C@@H](C)CCC=C(C)C)C[C@H]2C(C)=CC[C@H]12</smiles>

97<smiles>CC1(C)C[C@H](O)C[C@]2(C)OC(=O)C=C12</smiles>

98<smiles>CC(C)=CCCC(C)[C@H]1CCC(C)=C2CC=C(C)[C@H]2C1</smiles>

106: $\mathrm{X}^{1}=\mathrm{OH}, \mathrm{X}^{2}=\mathrm{H}$ 107: $\mathrm{X}^{1}=\mathrm{H}^{\prime} \mathrm{X}^{2}=\mathrm{H}$ 108: $\mathrm{X}^{1}={ }_{\mathrm{H}} \mathrm{X}^{2}=\mathrm{OCH}_{3}$

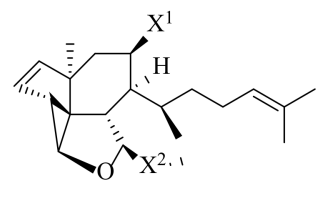<smiles>C=C1CC[C@H](C(C)(O)CCC=C(C)C)[C@H](O)[C@H]2C(C)=CC[C@H]12</smiles>

112<smiles>CCC(C)(C)O</smiles>

114<smiles>CC(C)=CCC[C@H](C)[C@@H]1CCC[C@H]2CC=C(C)[C@H]2[C@H]1O</smiles>

111<smiles>O=C1CCCCN1CCCCBr</smiles>

116
115<smiles>CC1(C)CCC2(C)C1C(=O)CCC2(C)C</smiles>

15

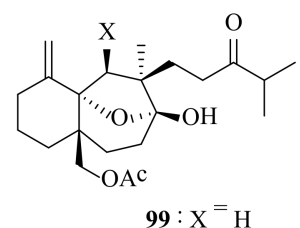
100: $\mathrm{X}=\mathrm{OH}$<smiles>C=C1CC[C@H]([C@H](C)CCC(=O)C(C)C)[C@H](O)[C@H]2C(C)=CC[C@H]12</smiles>

104

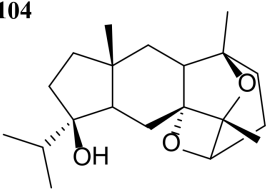

109

Figure 5. Chemical structures of compounds 88-118. The diterpenes 88-113 and 118, sterol 114, oxatricyclic derivative 115, halogenated derivative 116, and thiol derivative 117 were isolated from D. dichotoma. The configuration of all stereocenters in each compound is shown as given in the literature.

Sterols such as methyl-22-dehydrocholesterol, fucosterol (114), coprostanol (119), epicoprostanol (120), campesterol (121), stigmasterol (122), $\beta$-sitosterol (123), cholesterol (124), brassicasterol (125), cholestanol (126), and $5 \beta$-cholestan-3-one (127) (Figure 6) were discovered in the Malaysian D. dichotoma and tested for antifouling activity against Vibrio alginolyticus, V. mimicus, V. parahaemolyticus, P. aeruginosa, and B. subtilis. Coprostanol (119), epicoprostanol (120), campesterol (121), stigmasterol (122), and 5 $\beta$-cholestan-3-one (127) (Figure 6) showed strong inhibition towards the selected bacterial strains, with $\mathrm{IC}_{50}$ values ranging from 266.3 to $425.8 \mu \mathrm{g} / \mathrm{mL}$, while fucosterol (114) gave no activity for all bacterial strains tested. Epicoprostanol (120) was the most active compound; it inhibited two types of bacteria $V$. alginolyticus $(269.00 \pm 0.06)$ and $V$. mimicus $(314.81 \pm 0.07 \mu \mathrm{g} / \mathrm{mL})$ [63]. Fucosterol (114) had many biological activities, such as antiproliferative and antimicrobial [64]. 1- 
Octanol (128), p-cresol (129), 2,6-nonadienal (130), trans-anethole (131), $\alpha$-cubebene (132), $\beta$-bourbonene (133), $\beta$-cubebene (134), $\gamma$-gurjurene (135), germacrene $D(136), \alpha$-muurolene (137), $\alpha$-amorphene (138), $\delta$-cadenene (139), cis-calamenene (140), $\alpha$-calacorene (141), $\beta$ sesquiphellandrene (142), $\alpha$-cadinol (143), cembrene (144) (Figure 6), and palmitic acid were identified in the essential oil of $D$. dichotoma collected from the west of Algeria to the wilaya of Tipaza. With $10.7 \%$, trans-anethole (131) was the main component in the respective oils. For extracts of $D$. dichotoma, the dichloromethane extract was the most active one against DPPH radicals, with an $\mathrm{IC}_{50}$ value of $0.517 \mathrm{mg} / \mathrm{mL}$, followed by the chloroform extract $\left(\mathrm{IC}_{50}=0.612 \mathrm{mg} / \mathrm{mL}\right)$. The hexane extract of $D$. dichotoma displayed the lowest antiradical activity, with an $\mathrm{IC}_{50}$ value of $1.72 \mathrm{mg} / \mathrm{mL}$ [65].

Headspace-volatile organic compounds of fresh $D$. dichotoma, collected from the Adriatic Sea, Mala Smokvica Island, were: ethanol, oct-1-en-3-ol, octan-1-ol, decan-1ol, (2Z)-pent-2-en-1-ol, dimethyl sulfide, benzene, toluene, pent-1-en-3-one, oct-1-en-3one, 6-methylhept-5-en-2-one, (2E)-pent-2-enal, 3-methylbut-2-enal, (2E)-oct-2-enal, benzaldehyde, pentanal, hexanal, heptanal, nonanal, (2Z)-hept-2-enal, (2E,4Z)-hepta-2,4dienal, (3E)-octa-1,3-diene, fucoserraten, (2E,4E,6E)-octa-2,4,6-triene, heptadecane, nonadecane, $\alpha$-cubebene (132), $\beta$-bourbonene (133), $\beta$-cubebene (134), germacrene D (136), $\alpha$ muurolene (137), $\alpha$-amorphene (138), $\delta$-cadenene (139), $\alpha$-calacorene (141), $\alpha$-cadinol (143), cycloisosativene (145), $\tau$-muurolol (146), $\alpha$-ylangene (147), $\delta$-selinene (148), $\alpha$-copaene (149), aromadendrene (150), (E)- $\beta$-farnesene (151), $\alpha$-curcumene (152), bicyclogermacrene (153), epizonarene (154), $\gamma$-cadinene (155) (Figure 6), $\gamma$-muurolene (156), germacrene B (157), trans-cadina-1,4-diene (158), and 1,8-cineole (159) [66].

6-Hydroxydolabella-3,7,12-triene (160), 9-hydroxyisodolasta-1,3,5(14)-trienone (161), 9-hydroxydolasta-1,3-diene (162), 3,4-epoxy-6-hydroxydolabella-7,12-diene (163), $12-$ hydroxydolabella-3Z,7E-dien-2-one (164), 9,13-dihydroxydolasta-1,3-diene (165), 13-acetoxy9-hydroxydolasta-1,3-diene (166) and 9-hydroxydolasta-1,3-dien-13-one (167) (Figure 7) are diterpenes detected in the crude chloroform-methanol extract of $D$. dichotoma var. divaricata, collected from the coast of Neil Island in the Andamans [67].

17,18:18,19-Bisepoxyxenic-methoxy-triene (168), 3ß-hydroxydilophol (169), and 18hydroxy-2,7-dolabelladiene (170) (Figure 7) were identified in D. dichotoma var. divaricata collected from the Great Barrier Reef region of Northern Australia [68]. 4,17-Hydrosyxenictrienaloic acid lactone (171), 17-xenic-trien-1-al-18-oic acid lactone (172), epoxyxenichydroxydienaloic acid lactone (173), 17-acetoxyxenic-4-hydroxy-trien-dial (174), 17-acetoxy$4 \alpha$-hydrocrenulide (175), deacetoxydictyol H (176), and 2-hydroxydictyoxide (177) (Figure 7) were detected in D. dichotoma var. divaricata, collected from Australia [69].

(3 $\alpha \mathrm{S}, 4 \alpha \mathrm{R}, 8 \mathrm{~S}, 8 \alpha \mathrm{S})-4 \alpha$-Hydroxy-3 $\alpha, 8 \alpha$-dimethyl-5-methylidene-1-(propan-2-yl)-3,3 $\alpha$, $4,4 \alpha, 5,6,7,8,8 \alpha, 9$-decahydrobenzo[f]azulen-8-yl acetate (178), $(3 \alpha S, 4 \alpha R, 8 S, 8 \alpha S, 10 S)-4 \alpha, 8$ dihydroxy-3 $\alpha, 8 \alpha$-dimethyl-5-methylidene-1-(propan-2-yl)-2,3,3 $\alpha, 4,4 \alpha, 5,6,7,8,8 \alpha, 9,10$ dodecahydrobenzo[f]azulen-10-yl acetate (179), $(3 \alpha S, 4 \alpha R, 8 S, 8 \alpha S, 10 S)-4 a-h y d r o x y-3 \alpha, 8 \alpha-$ dimethyl-5-methylidene-1-(propan-2-yl)-2,3,3 $\alpha, 4,4 \alpha, 5,6,7,8,8 \alpha, 9,10$-dodecahydrobenzo[f] azulene-8,10-diyl diacetate (180) and $(3 \alpha S, 4 \alpha R, 8 \alpha R, 10 S)-4 \alpha$-hydroxy-3 $\alpha, 8 \alpha$-dimethyl-5methylidene-1-(propan-2-yl)-2,3,3 $\alpha, 4,4 \alpha, 5,6,7,8,8 \alpha, 9,10$-dodecahydrobenzo[f]azulen-10-yl acetate (181) (Figure 7) are tricyclic diterpenoids of the dolastane ring system detected in D. dichotoma var. divaricata, collected from the Caribbean Sea [70].

Divarinone (182), a tricyclic diterpene, was found in D. dichotoma var. divaricata collected from the Indian Ocean [71]. Pachydictyol A (14), isopachydictyol A (17), dictyol C (24), dolabellatrienol (183), amijiol acetate (184), dolastane amijiol-7,10-diacetate (185), 8 $\beta$ hydroxy-pachydictyol A (186), and amijiol (187) (Figure 7) were identified in D. dichotoma var. implexa. collected from the Red Sea. Among these compounds, amijiol acetate (189) and dolastane amijiol-7-10-diacetate (161) had potent activity against DNA damage, cytotoxicity against WI-38, HepG2, and MCF-7 cell lines, and showed antioxidant activity using ABTS and erythrocyte hemolysis [72].

Pachydictyol A (14), dictyol B acetate (18), and dictyol I acetate (188) (Figure 7) were found in D. dichotoma var. implexa obtained from the Northern Adriatic Sea [73]. Indicol 
(189), indcarol acetate (190), isolinearol (191), and linearol (192) (Figure 8) are secodolastane diterpenoids found in D. dichotoma var. indica from the Arabian Sea [74]. The first total synthesis of racemic isolinearol (191) was accomplished from commercially available 2methyl-1,3-cyclohexanedione in a total of 22 steps [75].

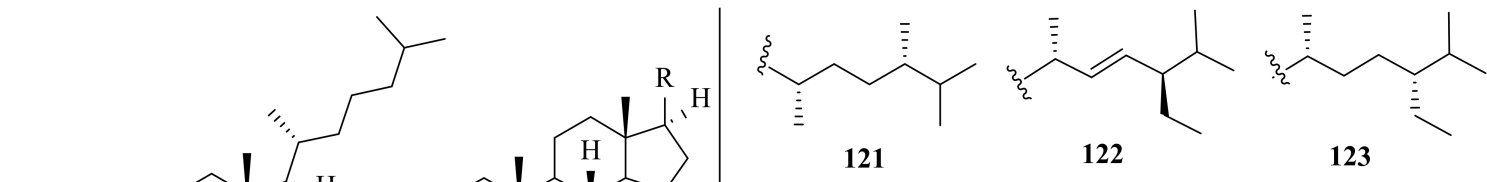

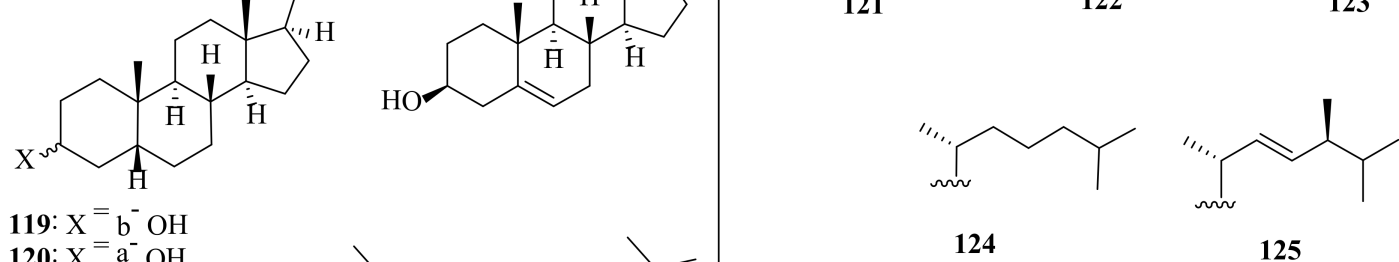
120: $\mathrm{X}^{=} \mathrm{a}^{-} \mathrm{OH}$

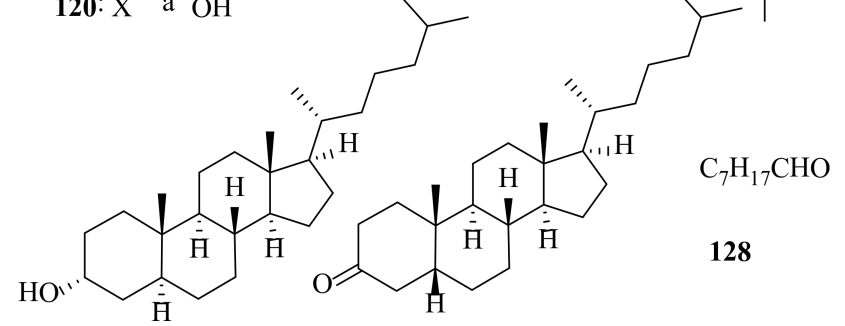<smiles>Cc1ccc(O)cc1</smiles><smiles>CC/C=C/CC/C=C/C=O</smiles><smiles>C/C=C/c1ccc(OC)cc1</smiles>
126

127 129 131<smiles>CC1=CC[C@@]2(C)[C@@H](C)CCC(C(C)C)[C@H]2C1</smiles>

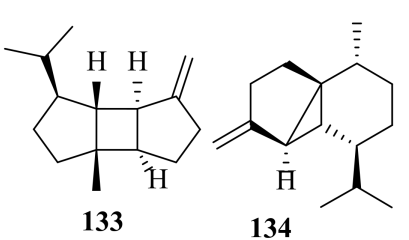<smiles>C=C(C)[C@@H]1C=C2[C@@H](CC[C@H]2C)[C@H](C)CC1</smiles><smiles>C=C(/C=C\C(CC/C(C)=C\CC(C)(C)C)C(C)C)CC</smiles><smiles>CC1=C[C@H]2C(C(C)C)CC=C(C)[C@H]2CC1</smiles><smiles>CC1=C[C@H]2C(C)=CC[C@H](C(C)C)[C@H]2CC1</smiles><smiles>CC1=C(P)C2C(=C(C)CC1)CCC2C(C)C</smiles><smiles>CC1CCC(C(C)C)c2ccccc21</smiles><smiles>CC1=CCC(C(C)C)c2ccccc21</smiles>
135 139<smiles>C=C1C=C[C@H]([C@@H](C)CCC=C(C)C)CC1</smiles><smiles>CC1=C[C@H]2[C@@H](C(C)C)CCC(C)(O)[C@@]2(C)CC1</smiles><smiles>C=C(C)[C@@H](CC)C/C=C(/C)CC/C=C(/C)CC/C=C(\C)CC</smiles>

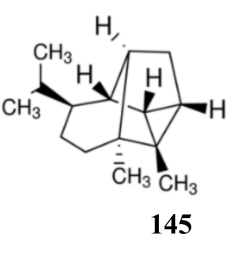

144<smiles>CC1=C[C@H]2C(C(C)C)CC[C@H](C)[C@H]2CC1</smiles>

146<smiles>CC1=CC[C@H]2C[C@H](C)[C@@H]1[C@H]2C(C)C</smiles>

147

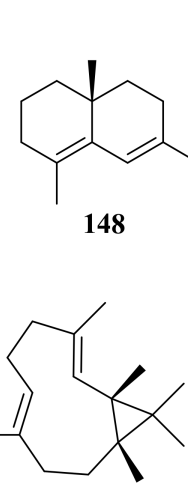

153

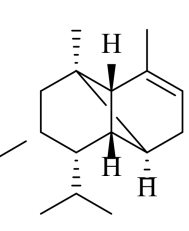

149<smiles>C=C1CCC2[C@H]([C@H]3CCCC13)C2(C)C</smiles><smiles>C=CC(=C)CC/C=C(\C)CCC=C(C)C</smiles>

151<smiles>CC(C)=CCC[C@H](C)c1ccc(C)cc1</smiles>

152<smiles>CC1=CC2=C(C(C)C)CC[C@H](C)[C@H]2CC1</smiles>

154<smiles>C=C1CC[C@H](C(C)C)[C@H]2C=C(C)CC[C@H]12</smiles>

155

Figure 6. Chemical structures of compounds 119-155. Sterols 119-127, aldehydes 128 and 130, aromatic derivatives 129, 131, and 152, diterpenes 132-133, sesquiterpenes 134-150 and 153-154, and hydrocarbon 151 were isolated from $D$. dichotoma. The configuration of all stereocenters in each compound is shown as given in the literature. 
<smiles>C=C1CC[C@H](C(C)C)[C@@H]2C=C(C)CC[C@@H]12</smiles>

156<smiles>CC1=C[C@H]2C(=CC1)[C@H](C)CC[C@@H]2C(C)C</smiles><smiles>CC12CCC(CC1)C(C)(C)O2</smiles><smiles>CC1=CC(O)CC(C)=CC[C@]2(C)CC=C(C(C)C)C2CC1</smiles><smiles>Cc1ccc(C)c2c1CCC1C(C(C)(C)C)CC[C@@]1(C)C2=O</smiles>

157<smiles>CC1=CC=C[C@]2(C)CCC3C(C(C)(C)C)CC[C@]3(C)C[C@H]12</smiles><smiles>CC1=C[C@H](O)C[C@](C)(O)C[C@@]2(C)CC=C(C(C)C)C2CC1</smiles><smiles>CC/C(C)=C\CC/C(C)=C\C(=O)[C@@]1(C)CC[C@@H](C(C)C)[C@@H]1C</smiles><smiles>[R2][C@H]1[C@@H]2C(C)=CC=C[C@]2(C)CC[C@H]2[C@](O)(C(C)C)CC[C@]12C</smiles>

165: $\mathrm{R}=\mathrm{H}$ 166: $\mathrm{R}=\mathrm{A}^{\mathrm{c}}$<smiles>CCCC[C@@H]1C2=CC=C(C)CC[C@H]3C2[C@H](OC[C@@H]3CCC=C(C)C)OC1OC</smiles><smiles>CC(C)=CCC[C@H](C)[C@H]1CCC2=CC[C@H](O)C(C)=C2[C@@H]1O</smiles>

169
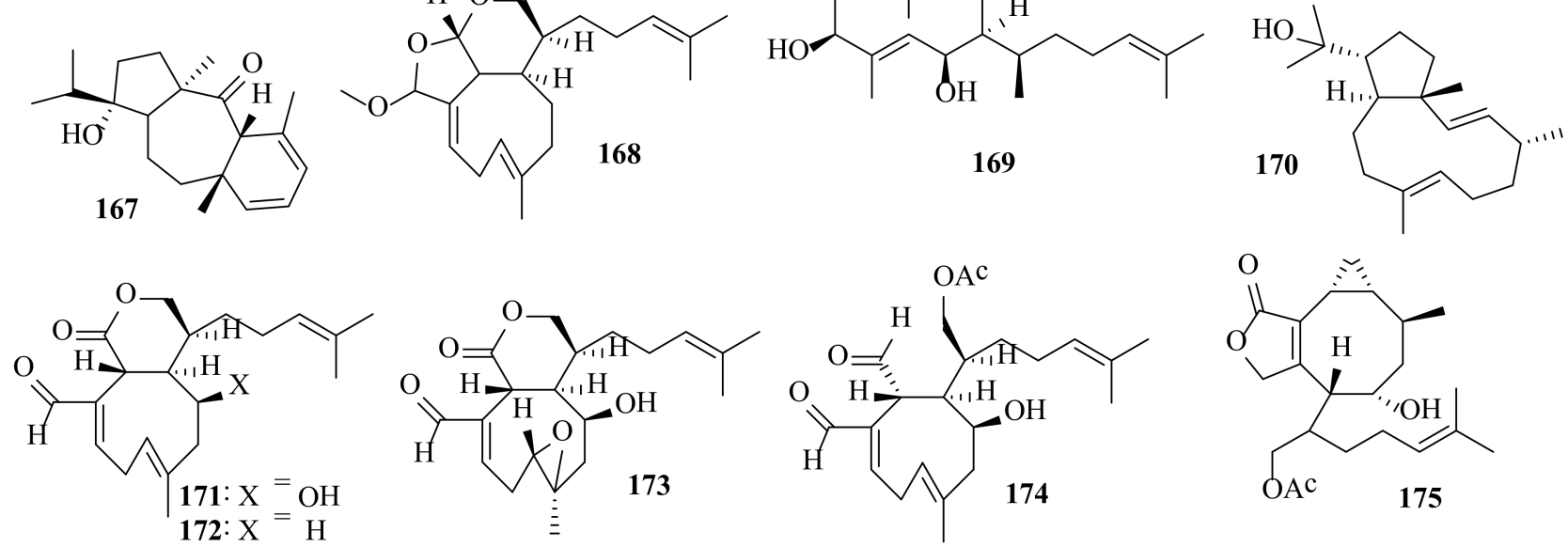

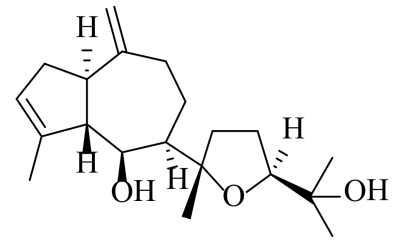

176

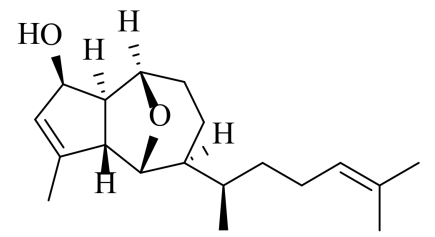

177<smiles>C=C1CC[C@H](C(C)=O)[C@@]2(C)CC=C3C(C(C)C)=CC[C@]3(C)C[C@]12O</smiles>

178

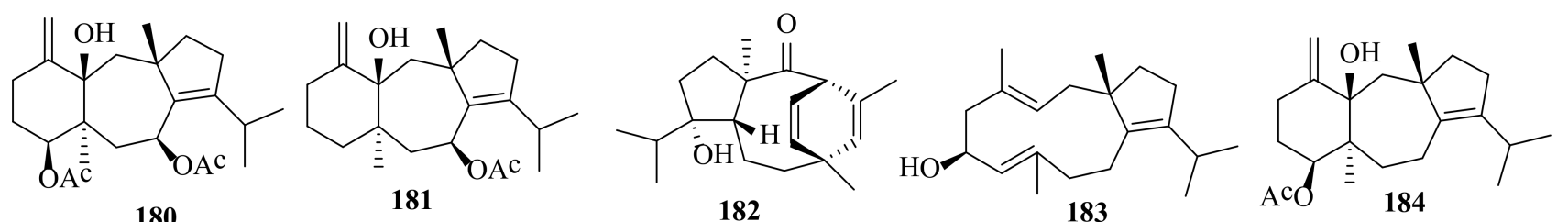

180<smiles>C=C1CC[C@@H](O)[C@@]2(C)C[C@H](OC(C)=O)C3=C(C(C)C)[C@@H](OC(C)=O)C[C@]3(C)C[C@]12O</smiles>

185<smiles>C=C1C[C@H](O)C([C@H](C)CCC=C(C)C)C(O)[C@H]2C(C)=CCC12</smiles>

186<smiles>C=C1CC[C@@H](O)[C@]2(C)CCC3=C(C(C)C)CC[C@]3(C)C[C@]12O</smiles>

187<smiles>C=C1CC[C@@H](O)[C@@]2(C)CC(OC(C)C)C3=C(C(C)C)CC[C@]3(C)C[C@]12O</smiles>

179

Figure 7. Chemical structures of compounds 156-188. Sesquiterpenes 156-159 were isolated from $D$. dichotoma, diterpenes 160-182 were isolated from $D$. dichotoma var. divaricata, and diterpenes 183-188 were isolated from $D$. dichotoma var. implexa. The configuration of all stereocenters in each compound is shown as given in the literature. 
<smiles>C=C1CCC[C@H](C)[C@@]12CCC(O)(O)[C@@H](CCC(=O)C(C)C)C2</smiles>

189<smiles>C=C1CC[C@H](O)[C@]2(CO)CC[C@]3(O)O[C@]12C[C@@]3(C)CCC(=O)C(C)C</smiles>

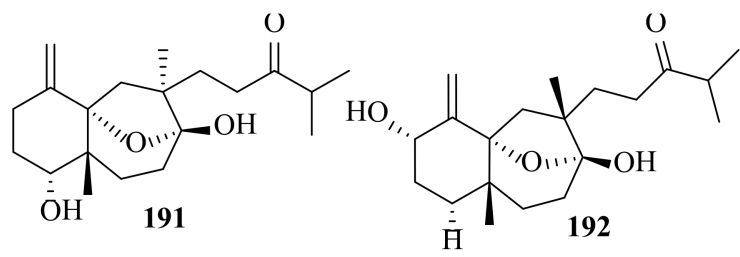<smiles></smiles>

193

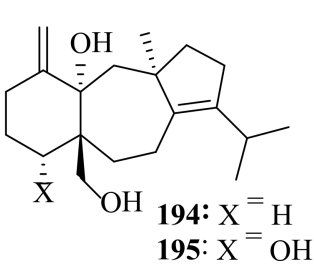

195: $\mathrm{X}=\mathrm{OH}$<smiles>C=C1CCC(C(C)CCC(O)C(C)(C)O)C(O)C1C1CC=CC1C</smiles><smiles>C=C1CCC(C(C)CC[C@@H](O)C(C)(C)O)C(O)C1C</smiles>

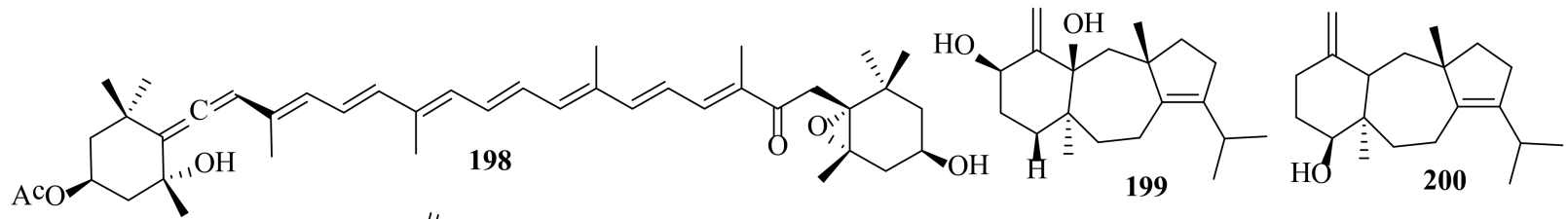<smiles>C=C1CCC(O)C2(C)CC3=C(C(C)C)CCC3C=C12</smiles><smiles>C=C1C(O)CCC2(C)CCC3=C(C(C)C)CC[C@H]3CC12</smiles><smiles>C=C1CCC(=O)C2(C)CC=C3C(O)(C(C)C)CC[C@]3(C)C[C@]12O</smiles>

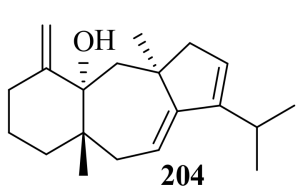<smiles>C=C1CCC(O)C2(C)C=CC3(C(C)C)CCC(O)(C3)C12C</smiles><smiles>C=C1CC[C@@H](O)[C@]2(C)C[C@H](O)C3=C(C(C)C)CC[C@H]3C[C@]12O</smiles>

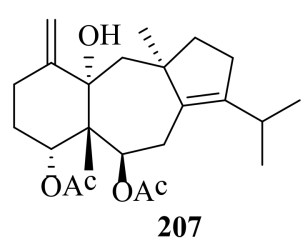<smiles>CC(C)=CCCC(C)C1CC=C(C=O)C2CC=C(C)[C@]21C</smiles><smiles>CC(C)=CCC[C@H](C)[C@H]1[C@H](C=O)/C(C=O)=C\C/C=C(/C)C[C@H]1O</smiles>

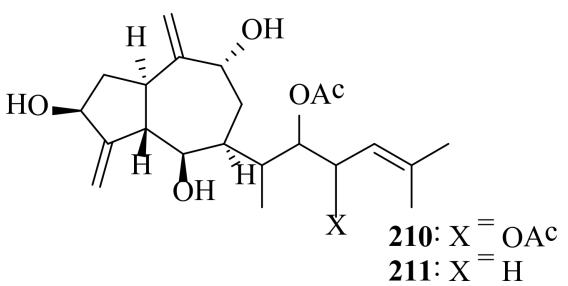

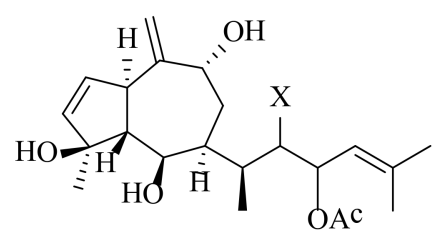
212: $\mathrm{X}=\mathrm{OAC}^{\mathrm{C}}$ 213: $X={ }_{H}$<smiles>C=C(C)C(O)CC(OC(C)=O)C(C)C1C[C@H](O)C(=C)C2CC=C(C)C21C</smiles>

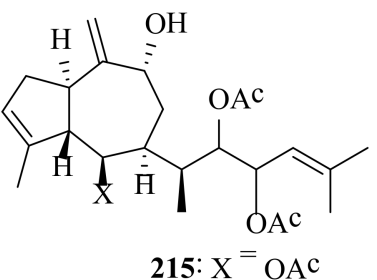<smiles>C=C1C(O)CC(C(C)C(C=CC(C)(C)O)OC(C)=O)C(O)C2C(C)=CCC12</smiles>
217<smiles>C=C1C(O)CC([C@H](C)C(C)O)C(O)[C@@]2(C)[C@@H]1C=CC2(C)O</smiles>

218<smiles>CC(C)=CCCC(C)C1CCC=CCCC1C</smiles>

219

216: $\mathrm{X}=\mathrm{OH}$

Figure 8. Chemical structures of compounds 189-219. Diterpenes 189-197 and carotenoid 198 were isolated from $D$. dichotoma var. indica, diterpenes 199-209 were isolated from D. dichotoma var. linearis, and diterpenes 210-219 were isolated from $D$. dichotoma var. volubilis. The configuration of all stereocenters in each compound is shown as given in the literature.

Dictinol (193), dictindiol (194), and dictintriol (195) (Figure 8) are dolastane diterpenoids that have been isolated from the acetone extract of D. dichotoma var. indica. [76]. 
Dictyotriol A (196) and dictyotriol B (197) were detected in D. dichotoma var. indica collected from the Yellow Sea [77].

Fucoxanthin (198) was extracted from D. dichotoma var. indica, collected from Qeshm Island, Persian Gulf. In a $24 \mathrm{~h}$ treatment at a concentration of $50 \mu \mathrm{g} / \mathrm{mL}$, it displayed effective anticancer activity against the breast cancer cell line, without toxic effects to the normal cells [78,79].

Palladium oxide nanoparticles using the extract of $D$. dichotoma var. indica collected from the Oman Sea coasts in Chabahar, Iran, have a spherical shape with an average particle diameter of $19 \mathrm{~nm}$ [80]. Polyshaped gold nanoparticles derived from an extract of leaves from $D$. dichotoma of size $8 \pm 21 \mathrm{~nm}$ were synthesized. Antibacterial activities were observed by the agar well diffusion method for the action of streptomycin and gentamycin and their formulation with biocapped gold nanoparticles. The profound efficacies were supported by the increase in fold area of inhibition against the tested bacteria [81].

Amijiol (187), isoamijiol (199), and 14-deoxyamijiol (200) were found in the methanolic extract of $D$. dichotoma var. linearis, collected from Japan [71,82]. Amijitrienol (201) and 14-deoxyisoamijiol (202) were detected in the methanolic extract of $D$. dichotoma var. linearis from Japan [83].

4-Acetoxy-9,14-dihydroxydolastadiene (203), 14-hydroxydolasta-1(15),7,9-triene (204), 4,9,14-trihydroxydolasta-1(15),7-diene (205), 4,7,14-trihydroxydolasta-1(15),8-diene (206), and 4,6-diacetoxy-14-hydroxydolastadiene (207), tricyclic diterpenes, were identified in the methanolic extract of $D$. dichotoma var. linearis, collected from Honduras Bay Islands. Crude extracts of $D$. dichotoma var. linearis and $D$. dichotoma var. divaricata showed toxicity to goldfish at $400 \mu \mathrm{g} / \mathrm{mL}$ (death in $90 \mathrm{~min}$ ) [84].

Isopachydictyolal (208) and $4 \alpha$-acetyldictyodial (209) were detected in the methanolic extract of $D$. dichotoma var. linearis. The antiviral activity of these metabolites isolated in adequate amounts was evaluated in laboratory assays against Herpes simplex virus I (HSV I) and poliomyelitis virus I, using Vero cells as the hosts [85].

2-Methyl-6-[(2S,3 $\alpha S, 4 R, 5 S, 7 R, 8 \alpha R)-2,4,7$-trihydroxy-3,8-dimethylidenedecahydroazulen5-yl]hept-2-ene-4,5-diyl diacetate (210), 6-methyl-2-[(2S,3 $\alpha S, 4 R, 5 S, 7 R, 8 \alpha R)$-2,4,7-trihydroxy-

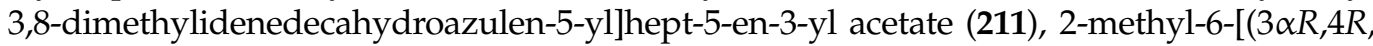
$5 S, 7 R, 8 \alpha R)$-3,4,7-trihydroxy-3-methyl-8-methylidene-3,3 $\alpha, 4,5,6,7,8,8 \alpha$-octahydroazulen-5-yl]

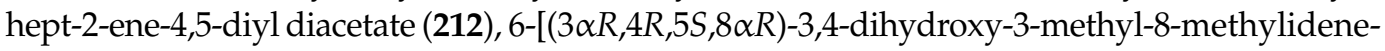
3,3 $\alpha, 4,5,6,7,8,8 \alpha$-octahydroazulen-5-yl]-2-methylhept-2-en-4-yl acetate (213), and 2-[(3 $\alpha S$, $4 R, 5 S, 7 R, 8 \alpha R)$-4,7-dihydroxy-3-methyl-8-methylidene-1,3 $\alpha, 4,5,6,7,8,8 \alpha$-octahydroazulen-5yl]-5-hydroxy-6-methylhept-6-en-3-yl acetate (214) are highly oxidized hydroazulenoid diterpenes from $D$. dichotoma var. volubilis [86].

Dictyol G acetate (11), 6-[(3 $\alpha S, 4 R, 5 S, 7 R, 8 \alpha R)$-4-(acetyloxy)-7-hydroxy-3-methyl8-methylidene-1,3 $\alpha, 4,5,6,7,8,8 \alpha$-octahydroazulen-5-yl]-2-methylhept-2-ene-4,5-diyl

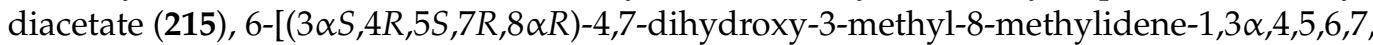

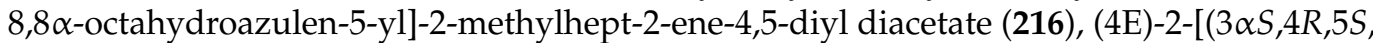
$7 R, 8 \alpha R)$-4,7-dihydroxy-3-methyl-8-methylidene-1,3 $2,4,5,6,7,8,8 \alpha$-octahydroazulen-5-yl]-6-

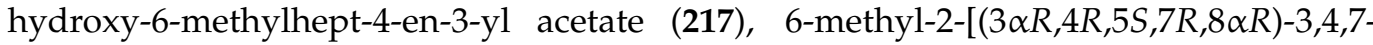
trihydroxy-3-methyl-8-methylidene-3,3 $\alpha, 4,5,6,7,8,8 \alpha$-octahydroazulen-5-yl]hept-5-en-3-yl acetate (218) and dilophol (219) are highly oxidized hydroazulenoid diterpenes from D. dichotoma var. volubilis collected from Geoffrey Bay (Australia) (Figure 8) [87].

The influence of temperature $\left(20,40\right.$, and $60^{\circ} \mathrm{C}$ ) and of the extraction solvents (water, ethanol) on the ultrasound-assisted extraction of phenolics from the Adriatic $D$. dichotoma was recorded. The extracts were analyzed for major phenolic sub-groups (total phenolics, flavonoids, and tannins), while the individual phenolics were detected by HPLC. The antioxidant activities were evaluated using three methods: ferric reducing/antioxidant power (FRAP), scavenging of the stabile 2,2-diphenyl-1-picrylhydrazyl (DPPH) radical, and the oxygen radical antioxidant capacity (ORAC). The total phenolics, flavonoids, and tannins were obtained using an alcoholic solvent, while a general conclusion about the applied temperature was not established. These extracts also showed good antioxidant 
activity, with high reducing capacity (690-792 mM TE) and ORAC values (38.7-40.8 mM TE in 400-fold diluted extracts). The PCA pointed out the significant influence of flavonoids and tannins on the investigated properties. The results of this investigation could be interesting for future studies dealing with the application of $D$. dichotoma in foods, cosmetics, and pharmaceuticals [88]. The aqueous and ethanolic extracts of the $D$. dichotoma, collected from Hurghada, the Red Sea coast of Egypt, exert an alleviation of salt stress on the germination of rice seeds at concentrations of $0,5,10,20$, and $50 \mathrm{~g} / \mathrm{L}$. The $\%$ germination of rice increased from $84 \%$ in non-treated seeds to $100 \%$ when treated with $20 \mathrm{~g} / \mathrm{L}$. The lower recovery of salt-treated seeds compared with the control seed germination suggests that rice suffered from the toxic ion effect of salinity on embryo rather than from the osmotic effect. Extracts of $D$. dichotoma can enhance and alleviate salinity stress on rice seed germination [89].

\subsection{Dictyota dumosa Børgesen 1935}

Several phytoconstituents were detected in the extracts of $D$. dumosa, D. dichotoma var. intricata, and D. dichotoma var. indica, collected from the Gulf of Mannar (India), where phenols, terpenoids, and cardiac glycosides were the major constituents. Antibacterial activity was tested against $K$. pneumoniae, S. aureus, P. aeruginosa, and B. subtilis, while antifungal activity was tested against $A$. niger, A. fumigatus, A. terreus, F. oxysporum, and C. albicans. Antibacterial activity was more promising in all the extracts of seaweed than antifungal activity, with the highest zone of inhibition of $17 \mathrm{~mm}$ shown by a methanolic extract of $D$. dumosa against $K$. pneumonia followed by $15 \mathrm{~mm}$ exerted by a chloroform extract of $D$. dichotoma var. indica against B. subtilis [90]. Fatty-acid analyses of $D$. dichotoma, D. dumosa, D. hauckiana, D. dichotoma var. indica, and D. maxima, found in Karachi coastal waters, evidenced the occurrence of ten saturated and four unsaturated fatty acids. Only palmitic acid occurred in all Dictyota species, while eicosatrienoic acid displayed a more selective distribution in $D$. indica [91].

\subsection{Dictyota fasciola (Roth) J.V. Lamouroux 1809}

The dichloromethane and dichloromethane/methanol extracts of $D$. fasciola showed noteworthy growth inhibition of marine bacteria and microalgae. Dictyol C (24), sanadaol (36), acetyldictyolal (37), dictyol E (112), neodictyolactone (220), and 18-hydroxy-2,7dolabelladiene (221) (Figure 9) were found in the crude extracts of $D$. fasciola collected from northern Tunisia [92].

\subsection{Dictyota fenestrata J. Agardh 1894}

Spatane-derived diterpenoids, secospatane (222) and 2-acetoxyspata-13(15),17-dien10-ol (223) were identified in the Australian species D. fenestrata (Figure 9) [93].

\subsection{Dictyota friabilis Setchell 1926}

Dolabelladienetriol (224), which was detected in D. friabilis, collected from Brazil, had a clear effect on HIV-1, inhibiting its replication in cell culture. Pretreatment with dolabelladienetriol (224) for $2 \mathrm{~h}$ or 1-5 days showed an inhibitory effect ranging from 60 to $90 \%$ in peripheral blood mononuclear cells (PBMCs) and macrophages infected with HIV-1, respectively. Dolabelladienetriol (224), after being subjected to the experimental model of ex vivo cervical mucosa, did not show any toxicity in concentrations between 14.4 and $0.15 \mu \mathrm{M}$. The protective effect of dolabelladienetriol (224) in an explant model in the uterine cervix was evaluated. The results show a curve of dose-dependent inhibition upon treatment with different concentrations of the compound in the presence of HIV-1 with $20-99 \%$ in concentrations of 0.15 and $14.4 \mu \mathrm{M}$, respectively (Figure 9) [94]. 

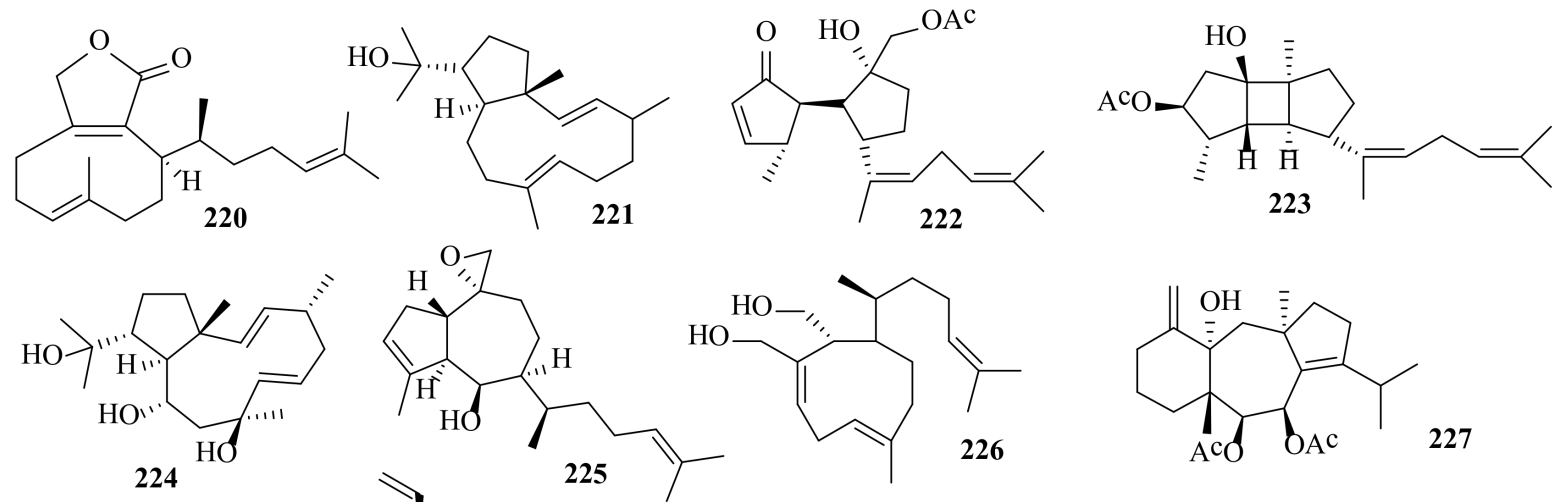<smiles>C=C[C@H](CC[C@H](C)[C@]1(O)CC[C@H]2[C@H]3CC=C4C[C@@H](O)CC[C@]4(C)C3CC[C@]21C)C(C)C</smiles>

228<smiles>[Y]C[C@]1(C(C)CCC=C(C)C)CC[C@H](C)[C@@H]2C[C@H]2C2=C1C(=O)OC2</smiles>

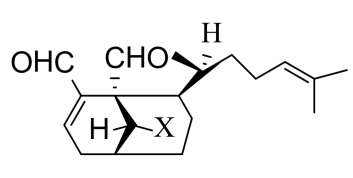

235: $\mathrm{X}=\mathrm{OH}$ 236: $X=O^{c}$

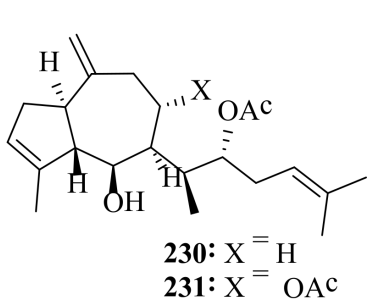<smiles>CC(C)=CCCC(C)C1C(=O)C=C(CO)C2CC=C(C)C2C1O</smiles>

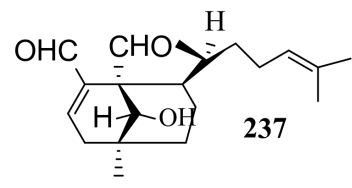<smiles>CC1C=CC2(C)CC[C@H](C(C)(C)O)C2C(O)CC(C)CC1</smiles>

238<smiles>COC(C)(C)[C@H](O)CC[C@H](C)[C@H]1C[C@@H](O)[C@]2(C)O[C@@]23CC[C@@]2(C)O[C@@]32O1</smiles><smiles>CC(C)=CCCC(C)[C@H]1CC[C@H](O)[C@@H]2CC=C(C)[C@H]2[C@H]1O</smiles>

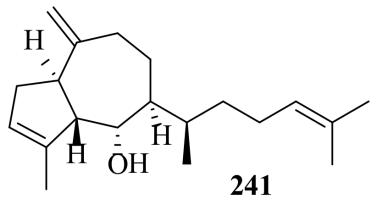<smiles>CC(=O)OC[C@H]1C(C)=CC=C(C)CC[C@@H]1[C@@H](C)CCC=C(C)C</smiles><smiles>[R]O[C@H]1OC/C2=C/C/C=C(/C)C[C@H](O)[C@H]([C@H]2C)[C@H]1[C@H](C)CC=C(C)C</smiles>

243: $\mathrm{R}=\mathrm{H}$<smiles>C=C(C)C(CC[C@@H](C)[C@@H]1C(COC(C)=O)C(C=O)=CCC=C(C)C[C@H]1O)OC</smiles>

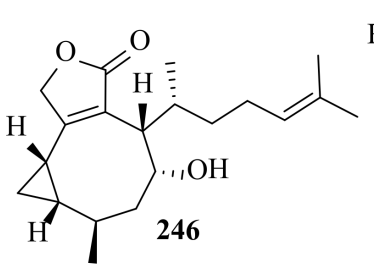

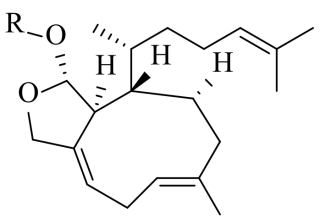

244: $\mathrm{R}=\mathrm{CH}_{3}$<smiles>COC1OCC2/C1=C\C/C=C(/C)C[C@H](O)[C@H]2[C@H](C)CCC=C(C)C</smiles>

249

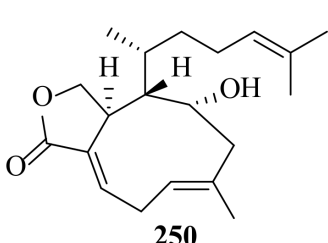

250

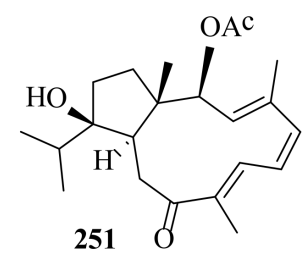

247: $\mathrm{R}^{=} \mathrm{H}$

248: $\mathrm{R}=\mathrm{CH}_{3}$

Figure 9. Chemical structures of compounds 220-251. Diterpenes 220-221 were isolated from $D$. fasciola, diterpenes 222-223 were isolated from $D$. fenestrate, diterpene $\mathbf{2 2 4}$ was isolated from D. friabilis, diterpenes 225-227 were isolated from $D$. furcellata, sterol 228 was isolated from D. hauckiana, diterpenes 229-239 were isolated from D. menstrualis, diterpenes 240-242 were isolated from $D$. pinnatifida, and diterpenes 243-251 were isolated from D. plectens. The configuration of all stereocenters in each compound is shown as given in the literature. 


\subsection{Dictyota flabellata (Collins) Setchell and N.L. Gardner 1924}

Pachydictyol-A epoxide (225) was detected in D. flabellata, collected at Sandy Beach, Puerto Peñasco, Sonora Mexico [95]. Dictyodial (26), dictyolactone (75), and dictyodiol (226) (Figure 9) were found in D. crenulata and D. flabellata collected from Hawaii [96]. The total polyphenol content $(70 \mathrm{mg} / 100 \mathrm{~g}$ fresh weight) and the vitamin $C$ content $(3 \mathrm{mg} / \mathrm{g}$ dry weight) in D. flabellata collected from Bahia Magdalena, Baja California Sur, Mexico, were determined [97].

\subsection{Dictyota furcellata (C. Agardh) Greville 1830}

In the Australian species D. furcellata, the dolastane diterpene derivative 6,7diacetoxydolasta-1(15),8-dien-14-ol (227) (Figure 9) was identified [98].

\subsection{Dictyota guineënsis (Kützing) P. Crouan and H. Crouan 1878}

In the crude extract of D. guineënsis, collected from Itamaracá Island (Brazil), five diterpenes were identified: dictyol $\mathrm{E}$ (112) (which was the most abundant diterpene), pachydictyol A (14), dictyoxide (15), isopachydictyol A (17), and dictyotadiol (118) [99].

\subsection{Dictyota hauckiana Nizamuddin 1975}

Hauckiosterol (228) was found in D. hauckiana, collected from the beaches of Hawkes Bay (New Zealand) [100]. Ethanolic extracts of $D$. dichotoma var. velutricata, D. dichotoma var. indica and D. hauckiana, occurring at Karachi Coast were screened for their cytotoxic activity using brine shrimp lethality for larvae (nauplii). The ethanolic extract of this species exhibited significant cytotoxicity $\left(\mathrm{LC}_{50}<1000 \mu \mathrm{g}\right)$ on brine shrimps. D. dichotoma var. indica showed the highest cytotoxic activity $\left(\mathrm{LC}_{50}=141 \mu \mathrm{g}\right)$, while $D$. hauckiana was found to be moderately effective on brine shrimp nauplii $\left(\mathrm{LC}_{50}=524 \mu \mathrm{g}\right)$. D. dichotoma var. velutricata were found to be less cytotoxic $\left(\mathrm{LC}_{50}=812 \mu \mathrm{g}\right)$ [101].

\subsection{Dictyota masonii Setchell and N.L. Gardner 1930}

The monocyclic diterpenoid hydroxydilophol (229) (Figure 9) was detected in the brown alga D. masonii collected from Isla (Spain) [102].

\subsection{Dictyota menstrualis (Hoyt) Schnetter, Hörning and Weber-Peukert 1987}

Dictyol C (24), acetoxycrenulide (33), dictyotin A (69), dictyol K (230), and dictyol M (231), dictyol N (232), isoacetoxycrenulatin (233), and 4-hidroxycrenulide (234) (Figure 9) were found in the Brazilian alga D. menstrualis. Anti-inflammatory, antimicrobial, and cytotoxic assays were performed with the isolated compounds, but only the anti-inflammatory activity was particularly prominent. The cell viability effects of the detected compounds on the murine macrophage cell line RAW 264.7 showed $\mathrm{IC}_{50}$ values from 1.12 to $2.53 \mu \mathrm{M}$, and the inhibitory activity against the nitric oxide production over the lipopolysaccharidestimulated RAW 264.7 cell line was observed for all compounds, with $\mathrm{IC}_{50}$ values ranging from 0.12 to $0.23 \mathrm{mM}$ [103].

The antiviral effect of the $\mathrm{CH}_{2} \mathrm{Cl}_{2} / \mathrm{MeOH}$-soluble fraction from the Brazilian D. menstrualis on HIV-1 replication was evaluated in vitro. The antiretroviral activity was attributed to two diterpenes: (6R)-6-hydroxydichotoma-3,14-diene-1,17-dial (235), and (6R)-6-acetoxidichotoma3,14-diene-1,17-dial (236). These dialdehydes affected an early step of the HIV-1 virus replicative cycle in a dose-dependent manner [104]. Moreover, the effects of three diterpenes, pachydictyol A (14), isopachydictyol A (17), and dichotomanol (237), on platelet aggregation and plasma coagulation were studied. Dichotomanol (237) inhibited ADP- or collagen-induced aggregation of platelet-rich plasma (PRP) but failed to inhibit washed platelets (WP). Pachydictyol A (14) and isopachydictyol A (17), by contrast, failed to inhibit the aggregation of PRP, but impaired WP aggregation induced by collagen or thrombin and inhibited coagulation, as analyzed by the prothrombin time and activated partial thromboplastin time and on commercial fibrinogen. Moreover, some of the isolated diterpenes inhibited the catalytic activity of thrombin [105]. 
(6R)-6-Hydroxydichotoma-4,14-diene-1,17-dial (235) and 8,10,18-trihydroxy-2,6dolabelladiene (238) were discovered in Brazilian D. menstrualis. They were found to inhibit HSV-1 infection in Vero cells. Compounds 235 and 238 (Figure 9) inhibited HSV-1 replication in a dose-dependent manner $\left(\mathrm{EC}_{50}=90\right.$ and $5.10 \mu \mathrm{M}$, respectively) [106].

Methanolic extracts of D. ciliolata (MEDC) and D. menstrualis (MED), collected from the Northeast of Brazil, were assessed as apoptosis-inducing agents on human cervical adenocarcinoma (HeLa) cells. All extracts showed different levels of cytotoxicity against the cells. In addition, MEDC and MEDM also inhibited SiHa (cervix carcinoma) cell proliferation. Studies with these two extracts showed that HeLa cells exposed to MEDM and MEDC exhibited morphological and biochemical changes that characterize apoptosis as shown by loss of cell viability, chromatin condensation, phosphatidylserine externalization, and sub-G1 cell cycle phase accumulation, and MEDC also induces cell cycle arrest in cell cycle phase S [107].

Extracted sulfated polysaccharides from Brazilian D. menstrualis, followed by separation into five fractions by sequential acetone precipitation, demonstrated that all fractions were composed mainly of fucose, xylose, galactose, uronic acid, and inorganic sulfate. The anticoagulant activity of these heterofucans was determined by activated partial thromboplastin time (APTT) using citrate normal human plasma. Only the fucans F1.0v and F1.5v showed anticoagulant activity. To prolong the coagulation time to double the baseline value in the APTT, the required concentration of fucan F1.0v $(20 \mu \mathrm{g} / \mathrm{mL})$ was only 4.88 -fold higher than that of the low-molecular-weight heparin Clexane ${ }^{\circledR}(4.1 \mu \mathrm{g} / \mathrm{mL})$, whereas $80 \mu \mathrm{g} / \mathrm{mL}$ fucan 1.5 was needed to obtain the same effect. For both fucans, the effect was abolished by desulfation [108].

A heterofucan (F2.0v) from D. menstrualis, collected from Búzios Beach, Rio Grande do Norte State (Brazil), was evaluated as an antinociceptive and anti-inflammatory agent. F2.0v $(20.0 \mathrm{mg} / \mathrm{kg})$ inhibited $100 \%$ of leukocyte migration into the peritoneal cavity after chemical stimulation. However, F2.0v did not alter the expression of interleukin-1 beta (IL-1 $\beta$ ) and interleukin-6 (IL-6), as well as tumor necrosis factor-alpha (TNF- $\alpha)$. F2.0v $(20.0 \mathrm{mg} / \mathrm{kg})$ had peripheral antinociceptive activity with potency like dipyrone. On the other hand, it did not affect pain response on the hot-plate test. Confocal microscopy analysis and flow cytometry showed that F2.0v binds to the surface of leucocytes, which leads us to suggest that the mechanisms of action of anti-inflammatory and antinociceptive F2.0v are related to its ability to inhibit the migration of leukocytes to the site of tissue injury. In summary, the data show that the F2.0v compound may have a great potential as an antinociceptive and anti-inflammatory agent [109]. The crude extract of Brazilian D. menstrualis and its derived fractions were analyzed for their antiviral potential, alone and in combination with ribavirin at $20 \mu \mathrm{g} / \mathrm{mL}$. The fractions that were rich in cyclic diterpenes with aldehyde groupings, inhibited Zika virus replication by $>74 \%$, with inhibition behaving in a dosedependent manner, with $\mathrm{EC}_{50}$ values of 2.80 (F-6) and 0.81 (FAc-2) $\mu \mathrm{g} / \mathrm{mL}$. Regarding the mechanism of action, FAc-2 had a strong virucidal potential, and F-6 inhibited viral adsorption. Associating FAc-2 with ribavirin at suboptimal dosages produced a strong synergistic effect that completely inhibited viral replication [110].

\subsection{Dictyota mertensii (C. Martius) Kützing 1859}

Fucan-coated silver nanoparticles (FN) from D. mertensii inhibited the proliferation of the melanoma tumor cell line B16F10 (60\%). In addition, they had immunomodulatory properties: They caused an up to 7000-fold increase in the release of nitric oxide and cytokines (IL-10; IL-6 and TNF- $\alpha$ ). In addition, the FN showed an inhibitory effect against both, Gram-positive and Gram-negative bacteria (MIC $=50 \mu \mathrm{g} / \mathrm{mL}$ ). Overall, the data showed that FN is a nanoparticle with the potential to be used as an antitumor, immunomodulatory, and antibacterial agent [111]. Pachydictyol A (14), isopachydictyol A (17), dictyol B acetate (18), dictyol C (24), and dictyol B (77) were isolated from D. mertensii [112]. 


\subsection{Dictyota pinnatifida Kützing 1859}

In D. pinnatifida, collected from the Colombian Caribbean, dictyoxepin (4), dictyol L (239), 6-epipachydictyol A (240), 6-epidictyol C (241), and 18-acetoxy-xenianol (242) were identified (Figure 9). Dictyol L (239) displayed strong inhibition of P. aeruginosa biofilms, better than kojic acid, which was used as the control. Dictyoxepin (4) showed mild inhibition of E. coli biofilms [113].

\subsection{Dictyota plectens (Allender and Kraft) Kraft 2009}

$4 \alpha$-Hydroxyisodictyohemiacetal (243), $4 \alpha$-hydroxyisodictyoacetal (244), 13,18-diacetoxy4-hydroxyisodictyo-19-al (245), $4 \alpha$-hydroxypachylactone (246), isodictyohemiacetal (247), isodictyoacetal (248), (2S,3S,4R,10R,19R)-19-deoxo-4-hydroxy-19-methoxydictyolactone (249), and 4-hydroxydictyolactone (250) (Figure 9) were found in the Chinese alga D. plectens. All compounds were evaluated for their antiviral activities against human immunodeficiency virus type 1 (HIV-1) replication activity. $4 \alpha$-Hydroxyisodictyohemiacetal (243) and isodictyoacetal (248) were active against the replication of wild-type HIV-1 virus with inhibitory concentration $50 \%\left(\mathrm{IC}_{50}\right)$ of 28.1 and $25.4 \mu \mathrm{M}$, while the other compounds were inactive at a concentration of $30.0 \mu \mathrm{M}$. Hydroxypachylactone (246) showed specific inhibition $(66.8 \%$ at $30.0 \mu \mathrm{M})$ against hemagglutinin (HA)-mediated highly pathogenic H5N1 infection utilizing an HIV-based pseudotyping system. $4 \alpha$-Hydroxypachylactone (246) and 4-hydroxydictyolactone (250) effectively inhibited lipopolysaccharide (LPS)-induced nitric oxide (NO) production in mouse peritoneal macrophages (PEM $\Phi)$, with inhibition rates of $76.0 \%$ and $53.2 \%$, respectively, at $10.0 \mu \mathrm{M}$, whereas the other compounds showed only weak activities [114]. (1S,2S,3E,5Z,7E,11R,12R)-2-acetoxy-12-hydroxydolabella-3,5,7-trien-9one (251) (Figure 9), (1S,2S,3E,5Z,7Z,11R,12R)-2-acetoxy-12-hydroxydolabella-3,5,7-trien-9one (252), (1S,2S,3S,4Z,6Z,8R,11R,12R)-2-acetoxy-12-hydroxydolasta -4,6-dien-9-one (253), $9 \alpha$-hydroxydictyol E (254), isodictyol E (255), 3 $\beta$-acetoxydilophol (256), and 19-acetyl-4hydroxydictyodiol (257) (Figure 10) were found in D. plectens collected from the South China Sea [115].

\subsection{Dictyota pulchella Hörnig and Schnetter 1988}

The cardiovascular effects elicited by $D$. pulchella were investigated using in vitro and in vivo experiments. In normotensive conscious rats, $\mathrm{CH}_{2} \mathrm{Cl}_{2} / \mathrm{MeOH}$ extract $(\mathrm{CME}, 5$, 10,20 , and $40 \mathrm{mg} / \mathrm{kg}$ ) from $D$. pulchella produced dose-dependent hypotension $(-4 \pm 1$; $-8 \pm 2 ;-53 \pm 8$; and $-63 \pm 3 \mathrm{mmHg})$ and bradycardia $(-8 \pm 6 ;-17 \pm 11 ;-257 \pm 36$; and $-285 \pm 27$ b.p.m.). In addition, the CME and hexane/EtOAc phases (HEP) $(0.01-300 \mu \mathrm{g} / \mathrm{mL})$ from $D$. pulchella induced a concentration-dependent relaxation in mesenteric artery rings pre-contracted with phenylephrine (Phe, $1 \mu \mathrm{M})$. The vasorelaxant effect was not modified by the removal of the vascular endothelium or by pre-incubation with $\mathrm{KCl}(20 \mathrm{mM})$, tetraethylammonium (TEA, $3 \mathrm{mM}$ ), or thromboxane A2 agonist U-46619 (100 nM). Furthermore, $\mathrm{CME}$ and $\mathrm{HEP}$ reversed $\mathrm{CaCl}_{2}$-induced vascular contractions. These results suggest that both CME and HEP acted on the voltage-operated calcium channel to produce vasorelaxation. In addition, CME-induced vasodilatation occurred after the vessels had been pre-contracted with an L-type $\mathrm{Ca}^{2+}$ channel agonist (Bay K 8644, $200 \mathrm{nM}$ ). Taken together, these data show that CME induced hypotension and bradycardia in vivo and that both CME and HEP induced endothelium-independent vasodilatation in vitro that seemed to involve the inhibition of the $\mathrm{Ca}^{2+}$ influx through the blockade of voltage-operated calcium channels [116]. Despite these interesting activities, no pure compounds have so far been isolated from this seaweed. 

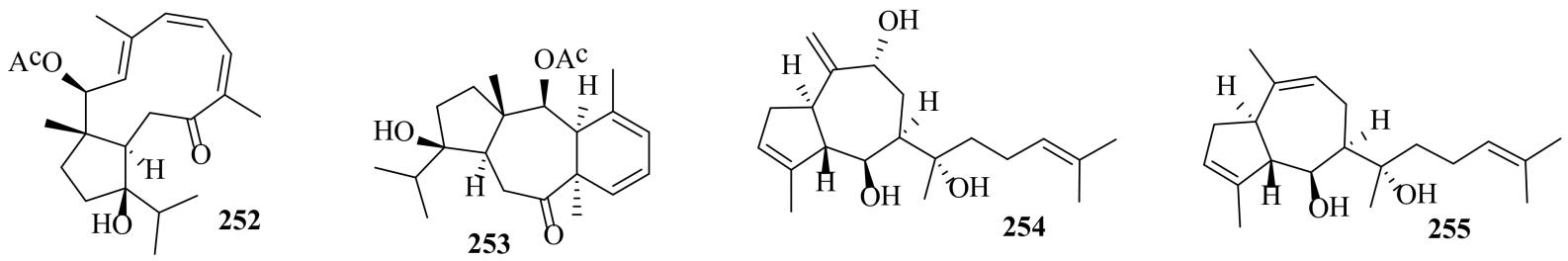

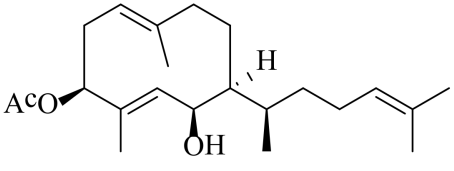

256

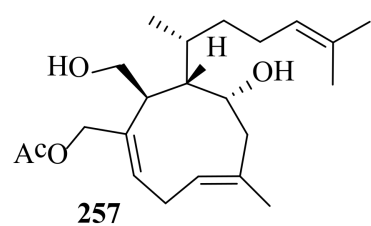

257<smiles>CC(C)=CCC[C@H](C)[C@H]1[C@H](O)C/C(C)=C\C/C=C(/C=O)[C@@H]1C=O</smiles><smiles>C=C(C)[C@H]1CC[C@](C)(CC=C(C)CCC=C(C)C)[C@@]1(C)CCO</smiles><smiles>C=C(C)C1CCC(C)(CC2(C)CO2)C1CC/C(C)=C/C</smiles>

260<smiles>C=C(C)[C@H]1C[C@@H](O)[C@]2(C)C[C@H]3O[C@]3(C)CCC/C=C/CC[C@H]12</smiles><smiles>C=C(C)[C@H]1CC(=O)[C@]2(C)[C@H]1CC/C(C)=C/CC[C@H]1O[C@]12C</smiles><smiles>C=C(C)[C@H]1CC(=O)[C@](C)(CC=C(C)C)[C@@H]1CC/C=C\CC</smiles><smiles>C=C(C)[C@H]1CC(=O)[C@](C)(CC/C=C(/C)CCC=C(C)C)[C@H]1C</smiles>

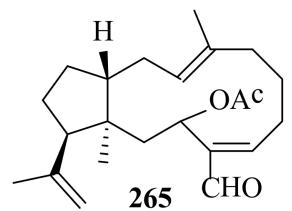

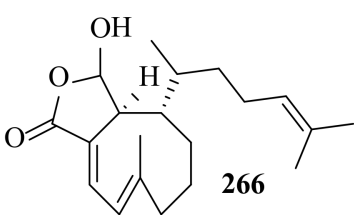<smiles>C=C1CC[C@H](C(C)C)[C@H](O)[C@@]2(O)[C@@H]1C[C@@H](OC(C)=O)C2(C)O</smiles>

267

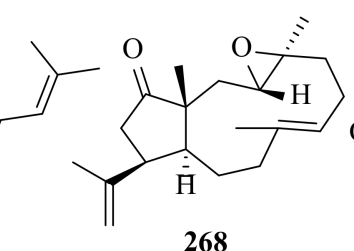<smiles>CO[C@@H]1[C@@H]([C@@H](C)CCC=C(C)C)C2=C(C(=O)OC2)[C@H]2C[C@H]2[C@H]1C</smiles><smiles>[R20]C1CC(C)=CCC[C@H](C)C=C[C@]1(C)CCC(C)(C)O</smiles><smiles>[R]OCC(O)CO</smiles><smiles>[R2]CCC(=O)CCCCCCC/C=C\CCCCCCCC</smiles><smiles>[R19]CC/C=C(\C)CC/C=C(\C)CC/C=C(\C)CCC=C(C)C</smiles>
270: $R=H$

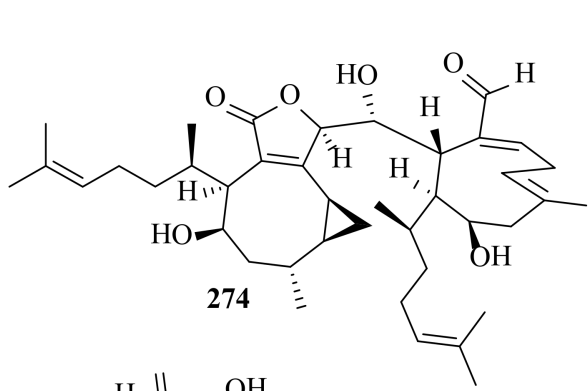

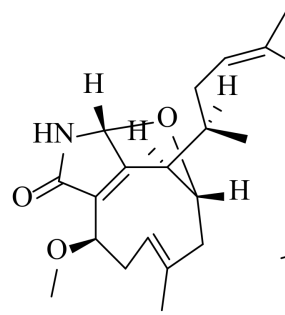

275<smiles>C=C1[C@H]2CC=C(C)[C@H]2C(O)C([C@@H](C)CC[C@@H](O)C(=C)C)=C[C@H]1O</smiles>

278<smiles>C=C1[C@@H](O)C=C([C@H](C)CC[C@@H](O)C(=C)C)C(O)[C@H]2C(C)=CC[C@H]12</smiles>

279<smiles>C=C(C)[C@H]1CC[C@]2(C)C/C(COC(C)=O)=C\CC/C(C)=C\C[C@H]12</smiles>

276<smiles>C=C1[C@H]2CC=C(C)[C@@H]2[C@@H](O)C([C@@H](C)C/C=C/C(C)(C)O)=C[C@H]1O</smiles>

280<smiles>C=C(C)[C@H]1CC[C@@]2(CC=C(C)CCC=C(C)C(OC(C)=O)C2)C1</smiles>

277

Figure 10. Chemical structures of compounds 252-281. Diterpenes 252-257 were isolated from D. plectens, diterpene $\mathbf{2 5 8}$ was isolated from D. spinulosa, diterpenes 259-227 were isolated from D. spiralis, and diterpenes $\mathbf{2 6 5}-\mathbf{2 7 1}$ and $\mathbf{2 7 4}-\mathbf{2 8 1}$ and glycerol derivatives $\mathbf{2 7 2 - 2 7 3}$ were isolated from Dictyota sp. The configuration of all stereocenters in each compound is shown as given in the literature. 


\subsection{Dictyota sandvicensis Sonder 1859}

D. sandvicensis is an edible Hawaiian seaweed. Its contents (\%) of water (relative to the total fresh weight), total ash, total soluble protein, total soluble carbohydrates and crude lipids (relative to the total dry weight) were measured $(86.4 \pm 0.3,28.9 \pm 0.1,6.4 \pm 0.6$, $6.7 \pm 0.4$, and $20.2 \pm 0.1$, respectively) [117]. No pure compounds have so far been isolated from this species.

\subsection{Dictyota spinulosa J.D. Hooker and Arnott 1838}

In D. spinulosa, collected from Kin, Okinawa (Japan), hydroxydictyodial (258) (Figure 10) was found. In feeding tests with Mozambique tilapia (Oreochromis mossambicus), it acted as an antifeedant diterpene [118],

\subsection{Dictyota spiralis Montagne 1846}

Spiralyde A (259), (1R,3S,4S,7E,11S,12S)-3,4-epoxy-7,18-dolabelladiene (260), (1R,3S, $4 S, 7 E, 11 S, 12 S, 14 S)$-3,4-epoxy-14-hydroxy-7,18-dolabelladiene (261), (1R,3S,4S,7E,11S,12S)3,4-epoxy-14-oxo-7,18-dolabelladiene (262), (1R,3E,7E,11S,12S)-14-oxo-3,7,18-dolabellatriene (263), and (1R,3Z,7E,11S,12S)-14-oxo-3,7,18-dolabellatriene (264) (Figure 10) were detected in D. spiralis, collected from the intertidal zone of the northwest coast of Tunisia. The dichloromethane extract of $D$. spiralis exhibited a promising antikinetoplastid capacity, with an $\mathrm{IC}_{50}$ of $9.76 \pm 0.55$ and $8.82 \pm 0.98 \mu \mathrm{g} / \mathrm{mL}$ against the promastigote form of Leishmani amazonensis and the epimastigote form of Trypanosoma cruzi, respectively. Among the compounds tested, spiralyde A (259) was the most active agent against L. amazonensis and T. cruzi [119]. Dictyol E (112), dolabellane (265), xenicane (266), prenylated guaiane (267), 3,4-epoxy-14-oxo-7,18-dolabelladiene (268), acetoxycrenulide (269), 10,18dihydroxydolabella-2,7-diene (270), 10-acetoxy-18-hydroxydolabella-2,7-diene (271), 1-Ooctadecenoylglycerol (272), and sn-3-O-(geranylgeranyl)glycerol (273) (Figure 10) were identified in Dictyota sp., collected from French and Algerian Mediterranean coastal sites. Compounds 268-269 and 271-273 were screened for their potential to prevent the adhesion of three bacterial strains isolated from marine biofilms in comparison with four commercial antifoulants. Compounds 272-273 exhibited the strongest anti-adhesion effects, with moderate toxicity [120].

Dictyotadimer A (274), a dissymmetric $C_{40}$ bis-diterpene, characterized by a C-C linkage between two different xenicane units, was discovered in the Mediterranean Sea grass Dictyota sp. [121]. Joalin (275) is the first nitrogen-containing xenicane diterpene detected in Dictyota sp., collected from the Senegalese Coast [122]. 16-Acetoxy-1R,11S,12Rdolabella-triene (276) and 3S-acetoxy-1R,11S,12R-dolabella-triene (277) (Figure 10) are minor dolabellane diterpenoid constituents from a Dictyota sp. [123]. The three hydroazulenoid diterpenes dictyotriol C (278), dictyotriol D (279), and dictyotriol E (280), along with $\alpha$-dictalediol monoacetate (281) (Figure 10), were identified in Dictyota sp., collected from the Canary Islands [124,125]. Pachydictyol C (111), Dictyol E (112), and 3,4-epoxy-7,18dolabelladiene have been identified in $D$. spiralis collected along the coast of Tunisia. In vitro evaluation of the trypanocidal activity exhibited $\mathrm{IC}_{50}$ values ranging from 13.11 to $35.28 \mu \mathrm{M}$ for these compounds; in comparison to benznidazole, which was active with an $\mathrm{IC}_{50}$ of $6.95 \mu \mathrm{M}$. Regarding cytotoxicity, $\mathrm{CC}_{50}$ values were found to range from $36.96 \mu \mathrm{M}$ for pachydictyol C (111) to $69.98 \mu \mathrm{M}$ for 3,4-epoxy-7,18-dolabelladiene compared to miltefosine and benznidazole [126]. Diterpenes such as dictyol C (24), (8R,11R)-8,11-diacetoxypachydictyol A, $\left(8 R^{*}, 11 R^{*}\right)$-6-O-acetyl-8-acetoxy-11-hydroxypachydictyol A, $\left(8 R^{*}, 11 S^{*}\right)$-8-acetoxy-11hydroxypachydictyol A, and $\left(8 R^{*}, 11 S^{*}\right)-6-O$-acetyl-8,11-dihydroxypachydictyol A, and a secohydroazulene derivative, named 7Z-7,8-seco-7,11-didehydro-8- acetoxypachydictyol A, were detected in Dictyota sp. collected from the South China Sea. The potent antioxidant effects against $\mathrm{H}_{2} \mathrm{O}_{2}$-induced oxidative damage in neuron-like PC12 cells took place at a low concentration of $2 \mu \mathrm{M}$. The antioxidant property of dictyol C (24) was associated with an activation of the Nrf2/ARE signaling pathway; it also showed neuroprotective effects against cerebral ischemia-reperfusion injury (CIRI) in a rat model of transient middle 
cerebral artery occlusion. As such, hydroazulene diterpenes could serve as lead structures for the development of novel neuroprotective agents against CIRI [127]

\section{Conclusions and Future Directions}

The genus Dictyota is one of the most important brown algae in the coastal zones because of its biomass and wide distribution in tropical to temperate seas. Despite the folk uses of brown algae, particularly of Dictyota, all over the world, the knowledge about its phytopharmacological potentials is still underexplored. Several species, such as $D$. divaricata, D. implexa, D. indica, D. linearis, and D. volubilis, have recently been considered the holotype of the genus Dictyota. Analysis of the reported data regarding its phytoconstituents has implied some remarkable gaps in the wholeness of our perception of their attribution to the reported biological activities and health outcomes of Dictyota, besides the roles performed by each of these metabolites. Moreover, existing biological research on several Dictyota species is particularly limited to the investigation of their total extracts or fractions, while the isolated components have so far received much less interest. Hence, further studies should comprehensively be done to discover the metabolites and their actual contribution to the medicinal properties of Dictyota, in addition to the implied mechanisms and their possible synergistic interactions, which would permit a sensible application of the genus Dictyota in modern phytotherapy. From a medicinal point of view, the antiproliferative potential of the genus Dictyota represents an indispensable future research theme. Many studies have extensively approached its cytotoxic properties. However, despite its reported cytotoxicity, the mechanism of action should be considered in future research to best appreciate this potential. Several dermal applications of the genus Dictyota were reported, such as hypopigmentation and anti-alopecia, yet so far without an application of these effects in cosmetic production. Species of the genus Dictyota were found to be cardioprotective and neuroprotective; however, further investigations are required for a full investigation of these effects and the effects on other body organs.

The antimicrobial potential is another considerable challenge because the current reported antimicrobial data are mostly restricted to crude extracts and fractions of Dictyota species. Although some of them exhibited high, broad-spectrum antimicrobial activities, a further detailed investigation of the antimicrobial properties of Dictyota following standardized protocols, involving those of the purified metabolites, is still missing and, hence, highly recommended. The investigation of the bioactive metabolites obtained from the genus Dictyota should be combined with more in-depth structure-activity relationship studies, and with the elucidation of their possible mechanisms of action. Elucidating the cellular and molecular features of the biological activities of Dictyota metabolites will be of pronounced value in the discovery and development of new bioactive compounds. Moreover, artificial analogs of bioactive metabolites of the genus Dictyota should be designed, synthesized, and tested, focusing on improving the efficacy and safety, and on increasing its economic production for nutrition with its further investigation as a natural source of new drugs.

Studies of nanotechnology could permit a safe and effective application of Dictyota species in modern phytotherapy. Many industrial applications as a source of biofuels and agricultural applications as a source of growth-promoting agents of this species are imaginable, but have not been sufficiently studied yet. The publication rate regarding Dictyota has been rising vigorously within the past five years (Figure 11), illustrating the rapidly growing interest in this intriguing genus. 


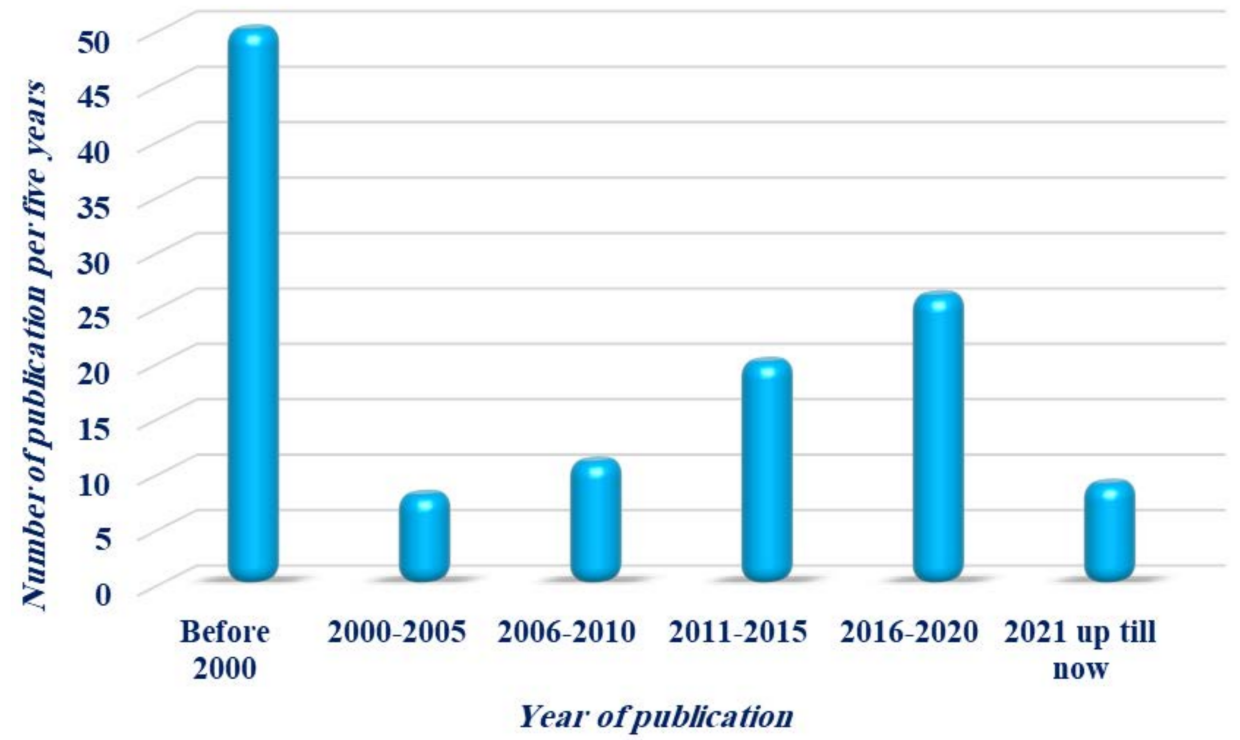

Figure 11. The rate of publication on the genus Dictyota.

So far, 25 species names of Dictyota, representing $24.5 \%$ of the current species, have been accepted taxonomically and investigated for their chemical and pharmacological activities (Figure 12), of which the most studied species as a possible drug source is D. dichotoma.

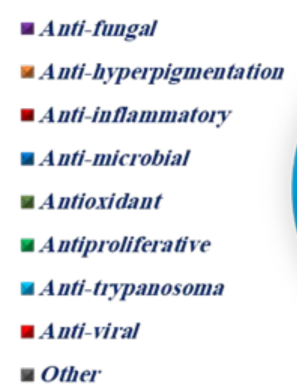

Pharmacological biodiversity

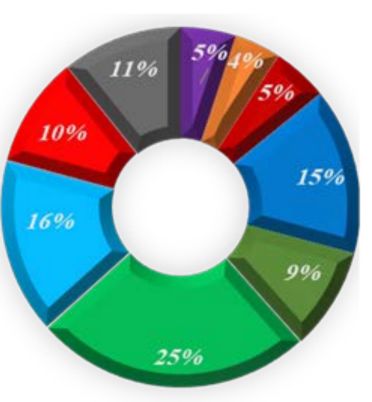

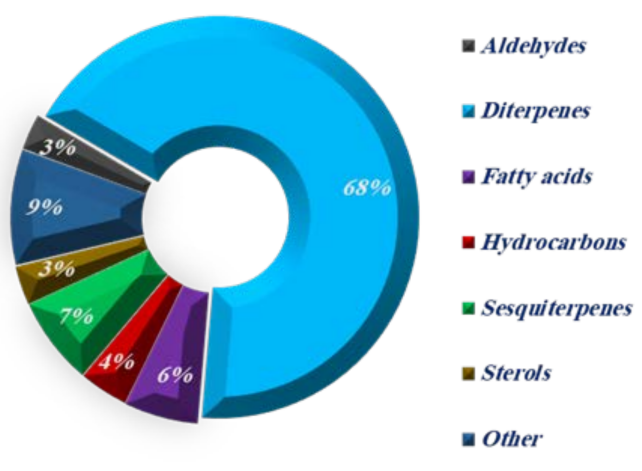

Phytochemical biodiversity

Figure 12. Pharmacological and phytochemical biodiversity of Dictyota.

Several bioactive compounds with most diverse chemical structures have been reported, including diterpenes sesquiterpenes, carotenoids, hydrocarbons, terpenes, sterols, and sulfated polysaccharides (Figures 2-10, Tables S1 and S2). These isolated compounds and/or extracts displayed diverse biological activities such as antiproliferative, antimicrobial, antiviral, antioxidant, anti-inflammatory, and anti-hyperpigmentation activities. In addition, fucoxanthin displayed antiproliferative activities towards different cancer cell lines. Moreover, the high polyphenolic content of some Dictyota sp. mainly reflects their antioxidant and antimicrobial activities. Finally, several Dictyota sp. extracts exhibited antiviral activities against HSV and HIV. The data compiled in the current review collectively highlight the potential of the genus Dictyota as a promising candidate for the development of alternative medicinal agents and, in the same context, the effective utilization of this alga as a functional-food ingredient, especially considering its known nutritional value, is also warranted. 
Supplementary Materials: The following supporting information can be downloaded, Table S1: Pharmacological potential of compounds isolated from the genus Dictyota; Table S2: Biological assays related to therapeutic potential of Dictyota extracts.

Author Contributions: M.I.R. and A.A.S. collected a complete survey of all compounds and their biological activities isolated from the genus Dictyota. M.I.R. wrote the manuscript. I.A.M.A.-R., H.S., U.R.A. and G.B. revised the surveyed literature data. E.Z.A., G.B. and U.R.A. discussed the results scientifically and contributed to the design and editing of the review. All authors have read and agreed to the published version of the manuscript.

Funding: This research received no external funding.

Acknowledgments: We would like to thank Ain Shams University, Minia University, and South Valley University for supporting this work.

Conflicts of Interest: The authors declare no conflict of interest.

\section{References}

1. Rushdi, M.I.; Abdel-Rahman, I.A.M.; Attia, E.Z.; Abdelraheem, W.M.; Saber, H.; Madkour, H.A.; Amin, E.; Hassan, H.M.; Abdelmohsen, U.R. A review on the diversity, chemical and pharmacological potential of the green algae genus Caulerpa. S. Afr. J. Bot. 2020, 132, 226-241. [CrossRef]

2. Rushdi, M.I.; Abdel-Rahman, I.A.M.; Saber, H.; Attia, E.Z.; Abdelraheem, W.M.; Madkour, H.A.; Hassan, H.M.; Elmaidomy, A.H.; Abdelmohsen, U.R. Pharmacological and natural products diversity of the brown algae genus Sargassum. RSC Adv. 2020, 10, 24951-24972. [CrossRef]

3. Guiry, M.; Guiry, G. AlgaeBase. World. 2022. Available online: https://www.algaebase.org/ (accessed on 8 January 2022).

4. Durán, R.; Zubía, E.; Ortega, M.J.; Salvá, J. New diterpenoids from the alga Dictyota dichotoma. Tetrahedron 1997, 53, 8675-8688. [CrossRef]

5. Rushdi, M.I.; Abdel-Rahman, I.A.; Saber, H.; Attia, E.Z.; Abdelmohsen, U.R. The natural products and pharmacological biodiversity of brown algae from the genus Dictyopteris. J. Mex. Chem. Soc. 2022, 66, 154-180. [CrossRef]

6. Pasqualetti, M.; Giovannini, V.; Barghini, P.; Gorrasi, S.; Fenice, M. Diversity and ecology of culturable marine fungi associated with Posidonia oceanica leaves and their epiphytic algae Dictyota dichotoma and Sphaerococcus coronopifolius. Fungal Ecol. 2020, 44, 100906. [CrossRef]

7. Bogaert, K.A.; Delva, S.; De Clerck, O. Concise review of the genus Dictyota J.V. Lamouroux. J. Appl. Phycol. 2020, 32, 1521-1543. [CrossRef]

8. Arokiarajan, M.S.; Thirunavukkarasu, R.; Joseph, J.; Ekaterina, O.; Aruni, W. Advance research in biomedical applications on marine sulfated polysaccharide. Int. J. Biol. Macromol. 2022, 194, 870-881. [CrossRef]

9. Chen, J.; Li, H.; Zhao, Z.; Xia, X.; Li, B.; Zhang, J.; Yan, X. Diterpenes from the marine algae of the genus Dictyota. Mar. Drugs 2018, 16, 159. [CrossRef]

10. Hardt, I.H.; Fenical, W.; Cronin, G.; Hay, M.E. Acutilols, potent herbivore feeding deterrents from the tropical brown alga, Dictyota acutiloba. Phytochemistry 1996, 43, 71-73. [CrossRef]

11. Sun, H.H.; Waraszkiewicz, S.M.; Erickson, K.L.; Finer, J.; Clardy, J. Dictyoxepin and dictyolene, two new diterpenes from the marine alga Dictyota acutiloba (Phaeophyta). J. Am. Chem. Soc. 1977, 99, 3516-3517. [CrossRef]

12. Solomon, R.D.J.; Santhi, V.S. Purification of bioactive natural product against human microbial pathogens from marine sea weed Dictyota acutiloba J. Ag. World J. Microbiol. Biotechnol. 2008, 24, 1747-1752. [CrossRef]

13. Rao, C.B.; Trimurtulu, G.; Sreedhara, C.; Rao, D.V.; Bobzin, S.C.; Faulkner, D.J. Diterpenes from the brown alga Dictyota bartayresiana. Phytochemistry 1994, 37, 509-513. [CrossRef]

14. Kumar, P.S.; Sudha, S. Biosynthesis of silver nanoparticles from Dictyota bartayresiana extract and their antifungal activity. Nano Biomed. Engl. 2013, 5, 72-75.

15. Antonysamy, J.M.A.; Velayutham, K.; Mani, N.; Thangaiah, S.; Irullappan, R. Antibacterial, cytotoxic and larvicidal potential of Dictyota bartayresiana Lamour. J. Coast. Life Med. 2015, 3, 352-355.

16. Palanisamy, S.; Sellappa, S.; Stella, C. Antioxidant properties of methanolic extract of Dictyota batresiana from south east coast of India. J. Pharm. Res. 2010, 3, 2974-2976.

17. Bharathi, D.S.; Boopathyraja, A.; Nachimuthu, S.; Kannan, K. Green Synthesis, Characterization and antibacterial activity of $\mathrm{SiO}_{2}-\mathrm{ZnO}$ nanocomposite by Dictyota bartayresiana extract and its cytotoxic effect on HT29 Cell Line. J. Clust. Sci. 2021, 3, 1-17. [CrossRef]

18. Pathirana, C.; Andersen, R.J. Diterpenoids from the brown alga Dictyota binghamiae. Can. J. Chem. 1984, 62, 1666-1671. [CrossRef]

19. Assef, A.N.B.; da Costa, B.B.; Moreira, T.A.; do Carmo, L.D.; de Souza, T.d.F.G.; Alencar, N.M.N.; Alves, A.P.N.N.; Cinelli, L.P.; Wilke, D.V. Antitumor and immunostimulating sulfated polysaccharides from brown algae Dictyota caribaea. Carbohydr. Polym. Technol. Appl. 2021, 2, 100142. [CrossRef] 
20. Brígido Assef, A.N.; da Costa, B.B.; Moreira, T.A.; do Carmo, L.D.; de Fátima Goebel de Souza, T.; Nunes Alencar, N.M.; Negreiros Nunes, A.P.; Cinelli, L.P.; Wilke, D.V. Antitumor sulfated polysaccharides from brown algae Dictyota caribaea. bioRxiv 2020, 2, 100142-100149.

21. Simas, D.L.R.; Kaiser, C.R.; Gestinari, L.M.; Duarte, H.M.; de Paula, J.C.; Soares, A.R. Diterpenes from the brown seaweed Dictyota caribaea (Dictyotaceae, Phaeophyceae): The ecological and taxonomic significance. Biochem. Syst. Ecol. 2014, 52, 33-37. [CrossRef]

22. Farias de Mesquita, M.M.; Baddini, A.L.d.Q.; Pereira Netto, A.D.; Magalhães de Araujo, J.; Salgueiro, F.; Lopes Filho, E.A.P.; De-Paula, J.C.; Fleury, B.G.; Cavalcanti, D.N.; Teixeira, V.L. Chemical similarity between Dictyota caribaea and Dictyota menstrualis (Dictyotaceae, Phaeophyceae) from the coast of Rio de Janeiro, Brazil. Biochem. Syst. Ecol. 2015, 58, 97-101. [CrossRef]

23. Manzo, E.; Ciavatta, M.L.; Bakkas, S.; Villani, G.; Varcamonti, M.; Zanfardino, A.; Gavagnin, M. Diterpene content of the alga Dictyota ciliolata from a Moroccan lagoon. Phytochem. Lett. 2009, 2, 211-215. [CrossRef]

24. Bourne, D.J.; Pilchowski, S.E.; Murphy, P.T. A novel sulfonoglycolipid from the brown alga Dictyota ciliolata. Aust. J. Chem. 1999, 52, 69-70. [CrossRef]

25. Caamal-Fuentes, E.; Moo-Puc, R.; Freile-Pelegrín, Y.; Robledo, D. Cytotoxic and antiproliferative constituents from Dictyota ciliolata, Padina sanctae-crucis and Turbinaria tricostata. Pharm. Biol. 2014, 52, 1244-1248. [CrossRef]

26. Yan, P.; Li, G.; Wang, C.; Wu, J.; Sun, Z.; Martin, G.E.; Wang, X.; Reibarkh, M.; Saurí, J.; Gustafson, K.R. Characterization by Empirical and Computational Methods of Dictyospiromide, an Intriguing Antioxidant Alkaloid from the Marine Alga Dictyota coriacea. Org. Lett. 2019, 21, 7577-7581. [CrossRef]

27. Ko, R.K.; Kang, M.-C.; Kim, S.S.; Oh, T.H.; Kim, G.-O.; Hyun, C.-G.; Hyun, J.W.; Lee, N.H. Anti-melanogenesis Constituents from the Seaweed Dictyota coriacea. Nat. Prod. Commun. 2013, 8, 427-428. [CrossRef]

28. Kang, J.-I.; Oh, T.H.; Kim, J.; No, H.; Lee, N.H.; Yoo, E.-S.; Kang, H.-K. The effect of 1,9-dihydroxycrenulide and epiloliolide from Dictyota coriacea on the hair growth. J. Herb. Med. 2021, 52, 134-142.

29. Kang, M.-C.; Lee, J.-Y.; Ko, R.-K.; Kim, H.-B.; Hong, S.-H.; Kim, G.-O. Melanin inhibitory effect and anti-inflammatory effects of Dictyota coriacea extracts derived from adjacent sea of the Jeju Island. KSBB J. 2008, 23, 311-316.

30. Kirkup, M.P.; Moore, R.E. Two minor diterpenes related to dictyodial A from the brown alga Dictyota crenulata. Phytochemistry 1983, 22, 2539-2541. [CrossRef]

31. Soto, H.; Rovirosa, J. A new diterpene from Dictyota crenulata. Z. Naturforsch. B 2003, 58, 795-798. [CrossRef]

32. Kirkup, M.P.; Moore, R.E. Identity of sanadaol with $\beta$-crenulal, a diterpene from the brown alga Dictyota crenulata. Phytochemistry 1983, 22, 2527-2529. [CrossRef]

33. De-Paula, J.C.; Bueno, L.B.; Cavalcanti, D.N.; Yoneshigue-Valentin, Y.; Teixeira, V.L. Diterpenes from the brown alga Dictyota crenulata. Molecules 2008, 13, 1253-1262. [CrossRef]

34. Nagaoka, H.; Kobayashi, K.; Yamada, Y. Total synthesis of (-)- and (+)-sanadaol: The absolute configuration of sanadaol and dictyodial. Tetrahedron Lett. 1988, 29, 5945-5946. [CrossRef]

35. El-Shenody, R.A.; Ashour, M.; Ghobara, M.M.E. Evaluating the chemical composition and antioxidant activity of three Egyptian seaweeds: Dictyota dichotoma, Turbinaria decurrens, and Laurencia obtusa. Braz. J. Food Technol. 2019, 22, 1-15. [CrossRef]

36. Usoltseva, R.V.; Shevchenko, N.M.; Malyarenko, O.S.; Ishina, I.A.; Ivannikova, S.I.; Ermakova, S.P. Structure and anticancer activity of native and modified polysaccharides from brown alga Dictyota dichotoma. Carbohydr. Polym. 2018, 180, 21-28. [CrossRef] [PubMed]

37. Malyarenko, O.S.; Usoltseva, R.V.; Zvyagintseva, T.N.; Ermakova, S.P. Laminaran from brown alga Dictyota dichotoma and its sulfated derivative as radioprotectors and radiosensitizers in melanoma therapy. Carbohydr. Polym. 2019, 206, 539-547. [CrossRef] [PubMed]

38. Rabanal, M.; Ponce, N.M.A.; Navarro, D.A.; Gómez, R.M.; Stortz, C.A. The system of fucoidans from the brown seaweed Dictyota dichotoma: Chemical analysis and antiviral activity. Carbohydr. Polym. 2014, 101, 804-811. [CrossRef]

39. Beula, J.M.; Ravikumar, S.; Ali, M.S. Mosquito larvicidal efficacy of seaweed extracts against dengue vector of Aedes aegypti. Asian Pac. J. Trop. Biomed. 2011, 1, S143-S146. [CrossRef]

40. Bakar, K.; Mohamad, H.; Latip, J.; Tan, H.S.; Herng, G. Fatty acids compositions of Sargassum granuliferum and Dictyota dichotoma and their anti-fouling activities. J. Sustain. Sci. Manag. 2017, 12, 8-16.

41. Araki, S.; Eichenberger, W.; Sakurai, T.; Sato, N. Distribution of Diacylglycerylhydroxymethyltrimethyl- $\beta$-alanine (DGTA) and Phosphatidylcholine in Brown Algae. Plant Cell Physiol. 1991, 32, 623-628. [CrossRef]

42. El-Shaibany, A.; Al-Habori, M.; Al-Maqtari, T.; Al-Mahbashi, H. The Yemeni brown algae Dictyota dichotoma exhibit high in vitro anticancer activity independent of its antioxidant capability. Biomed Res. Int. 2020, 2425693. [CrossRef] [PubMed]

43. Enoki, N.; Ishida, R.; Matsumoto, T. Structures and conformations of new nine-membered ring diterpenoids from the marine alga Dictyota dichotoma. Chem. Lett. 1982, 11, 1749-1752. [CrossRef]

44. Ishitsuka, M.O.; Kusumi, T.; Kakisawa, H. Antitumor xenicane and norxenicane lactones from the brown alga Dictyota dichotoma. J. Org. Chem. 1988, 53, 5010-5013. [CrossRef]

45. Kolesnikova, S.A.; Kalinovsky, A.I.; Fedorov, S.N.; Shubina, L.K.; Stonik, V.A. Diterpenes from the Far-eastern brown alga Dictyota dichotoma. Phytochemistry 2006, 67, 2115-2119. [CrossRef] [PubMed]

46. Rao, C.B.; Pullaiah, K.C.; Surapaneni, R.K.; Sullivan, B.W.; Albizati, K.F.; Faulkner, D.J.; Cun-heng, H.; Clardy, J. The diterpenes of Dictyota dichotoma from the Indian Ocean. J. Org. Chem. 1986, 51, 2736-2742. [CrossRef] 
47. Ishitsuka, M.O.; Kusumi, T.; Ichikawa, A.; Kakisawa, H. Bicyclic diterpenes from two species of brown algae of the Dictyotaceae. Phytochemistry 1990, 29, 605-2610. [CrossRef]

48. Kim, J.Y.; Alamsjah, M.A.; Hamada, A.; Fujita, Y.; Ishibashi, F. Algicidal Diterpenes from the Brown Alga Dictyota dichotoma Biosci. Biotechnol. Biochem. 2006, 70, 2571-2574. [CrossRef]

49. Fattorusso, E.; Magno, S.; Mayol, L.; Santacroce, C.; Sica, D.; Amico, V.; Oriente, G.; Piattelli, M.; Tringali, C. Dictyol A and B, two novel diterpene alcohols from the brown alga Dictyota dichotoma. J. Chem. Soc. Chem. Commun. 1976, 14, 575-576. [CrossRef]

50. Enoki, N.; Tsuzuki, K.; Omura, S.; Ishida, R.; Matsumoto, T. New antimicrobial diterpenes, dictyol F and epidictyol F, from the brown alga Dictyota dichotoma. Chem. Lett. 1983, 12, 1627-1630. [CrossRef]

51. Blount, J.; Dunlop, R.; Erickson, K.; Wells, R. Two diterpenes with new carbocyclic ring systems from an Australian collection of the brown alga Dictyota dichotoma. Aust. J. Chem. 1982, 35, 145-163. [CrossRef]

52. Kusumi, T.; Muanza-Nkongolo, D.; Goya, M.; Ishitsuka, M.; Iwashita, T.; Kakisawa, H. Structures of crenulacetals A, B, C, and D The new diterpenoids from the brown algae of Dictyotaceae. J. Org. Chem. 1986, 51, 384-387. [CrossRef]

53. Ali, M.S.; Pervez, M.K. seco-Dolastanes from the marine brown alga Dictyota dichotoma (Huds.) amour. Z. Naturforsch. B 2003, 58, 438-442.

54. Kolesnikova, S.A.; Lyakhova, E.G.; Kalinovsky, A.I.; Dmitrenok, P.S.; Dyshlovoy, S.A.; Stonik, V.A. Diterpenoid Hydroperoxides from the Far-Eastern Brown Alga Dictyota dichotoma. Aust. J. Chem. 2009, 62, 1185-1188. [CrossRef]

55. Segawa, M.; Enoki, N.; Ikura, M.; Hikichi, K.; Ishida, R.; Shirahama, H.; Matsumoto, T. Dictymal, a new Seco-fusicoccin type diterpene from the brown alga Dictyota dichotoma. Tetrahedron Lett. 1987, 2, 3703-3704. [CrossRef]

56. Ali, M.S.; Pervez, M.K.; Saleem, M.; Ahmed, F. Dichotenone-A and -B: Two New Enones from the Marine Brown Alga Dictyota Dichotoma (Hudson) Lamour. Nat. Prod. Res. 2003, 17, 301-306. [CrossRef]

57. Ali, M.S.; Pervez, M.K.; Ahmed, F.; Saleem, M. Dichotenol-A, B and C: The C-16 oxidized seco-dolastanes from the marine brown alga Dictyota dichotoma (Huds.) Lamour. Nat. Prod. Res. 2004, 18, 543-549. [CrossRef]

58. Nobuyasu, E.; Ryoichi, I.; Shiro, U.; Masamitsu, O.; Takashi, T.; Takeshi, M. New hydroazulenoid diterpenes from the marine alga Dictyota dichotoma. Chem. Lett. 1982, 11, 1837-1840.

59. Enoki, N.; Ishida, R.; Urano, S.; Matsumoto, T. New tricarbocyclic cycropropanoid diterpenes from the brown alga Dictyota dichotoma. Tetrahedron Lett. 1985, 26, 1731-1734. [CrossRef]

60. Pullaiah, K.C.; Surapaneni, R.K.; Rao, C.B.; Albizati, K.F.; Sullivan, B.W.; Faulkner, D.J.; He, C.H.; Clardy, J. Dictyoxetane, a novel diterpene from the brown alga Dictyota dichotoma from the Indian Ocean. J. Org. Chem. 1985, 50, 3665-3666. [CrossRef]

61. Abou-El-Wafa, G.S.E.; Shaaban, M.; Shaaban, K.A.; El-Naggar, M.E.E.; Maier, A.; Fiebig, H.H.; Laatsch, H. Pachydictyols B and C: New Diterpenes from Dictyota dichotoma Hudson. Mar. Drugs 2013, 11, 3109-3123. [CrossRef] [PubMed]

62. Faulkner, D.J.; Ravi, B.N.; Finer, J.; Clardy, J. Diterpenes from Dictyota dichotoma. Phytochemistry 1977, 16, 991-993. [CrossRef]

63. Bakar, K.; Mohamad, H.; Tan, H.S.; Latip, J. Sterols compositions, antibacterial, and antifouling properties from two Malaysian seaweeds: Dictyota dichotoma and Sargassum granuliferum. J. Appl. Pharm. Sci. 2019, 9, 047-053.

64. Rushdi, M.I.; Abdel-Rahman, I.A.M.; Saber, H.; Attia, E.Z.; Madkour, H.A.; Abdelmohsen, U.R. A review on the pharmacological potential of the genus Padina. S. Afr. J. Bot. 2021, 141, 37-48. [CrossRef]

65. Benfares, R.; Kord, A.; Boudjema, K.; Bouarab, M.; Benrabah, S.; Boudjemaa, K.; Švarc-Gajić, J. Chemical characterization of essential oils and antioxidant activity of Dictyota dichotoma and Dictyopteris membranacea. Acta Period. Technol. 2019, 33-42. [CrossRef]

66. Jerković, I.; Marijanović, Z.; Roje, M.; Kuś, P.M.; Jokić, S.; Čož-Rakovac, R. Phytochemical study of the headspace volatile organic compounds of fresh algae and seagrass from the Adriatic Sea (single point collection). PLoS ONE 2018, 13, e0196462. [CrossRef]

67. Rao, C.B.; Trimurtulu, G.; Rao, D.V.; Bobzin, S.C.; Kushlan, D.M.; Faulkner, D.J. Diterpenes from the brown alga Dictyota divaricata of the Indian Ocean. Phytochemistry 1991, 30, 1971-1976. [CrossRef]

68. König, G.M.; Wright, A.D.; Sticher, O. Diterpenes from the brown alga Dictyota divaricata. Phytochemistry 1991, 30, 3679-3682. [CrossRef]

69. König, G.M.; Wright, A.D.; Sticher, O. New xenicane and hydroazulenoid diterpenes from an Australian collection of Dictyota divaricata. Tetrahedron 1991, 47, 1399-1410. [CrossRef]

70. Sun, H.H.; McConnell, O.J.; Fenical, W.; Hirotsu, K.; Clardy, J. Tricyclic diterpenoids of the dolastane ring system from the marine alga Dictyota divaricata. Tetrahedron 1981, 37, 1237-1242. [CrossRef]

71. Trimurtulu, G.; Kushlan, D.M.; Faulkner, D.J.; Rao, C.B. Divarinone, a novel diterpene from the brown alga Dictyota divaricata of the indian ocean. Tetrahedron Lett. 1992, 33, 729-732. [CrossRef]

72. Ayyad, S.-E.N.; Makki, M.S.; Al-kayal, N.S.; Basaif, S.A.; El-Foty, K.O.; Asiri, A.M.; Alarif, W.M.; Badria, F.A. Cytotoxic and protective DNA damage of three new diterpenoids from the brown alga Dictoyota dichotoma. Eur. J. Med. Chem. 2011, 46, 175-182. [CrossRef]

73. De Rosa, S.; De Stefano, S.; Zavodnik, N. Hydroazulenoid diterpenes from the brown alga Dictyota dichotoma var. Implexa. Phytochemistry 1986, 25, 2179-2181. [CrossRef]

74. Bano, S.; Parveen, S.; Ahmad, V.U. Marine natural products, XIV. secodolastane diterpenoids of Dictyota indica from the Arabian Sea. J. Nat. Prod. 1990, 53, 492-495. [CrossRef]

75. Kobayashi, T.; Tomita, Y.; Kawamoto, Y.; Ito, H. Highly stereocontrolled total synthesis of secodolastane diterpenoid isolinearol. Org. Biomol. Chem. 2020, 18, 7316-7320. [CrossRef] [PubMed] 
76. Ahmad, V.U.; Parveen, S.; Bano, S.; Shaikh, W.; Shameel, M. Dolastane diterpenoids from the brown alga Dictyota indica. Phytochemistry 1991, 30, 1015-1018. [CrossRef]

77. Niang, L.L.; Hung, X. Studies on the biologically active compounds of the algae from the Yellow Sea. Hydrobiologia 1984, 116, 168-171. [CrossRef]

78. Karkhane Yousefi, M.; Seyed Hashtroudi, M.; Mashinchian Moradi, A.; Ghasempour, A. In vitro investigating of anticancer activity of focuxanthin from marine brown seaweed species. Glob. J. Environ. Sci. Manag. 2018, 4, 81-90.

79. Rushdi, M.I.; Abdel-Rahman, I.A.M.; Saber, H.; Attia, E.Z.; Abdelraheem, W.M.; Madkour, H.A.; Abdelmohsen, U.R. The genus Turbinaria: Chemical and pharmacological diversity. Nat. Prod. Res. 2020, 35, 4560-4578. [CrossRef]

80. Yazdani, A.; Sayadi, M.; Heidari, A. Green biosynthesis of palladium oxide nanoparticles using Dictyota indica seaweed and its application for adsorption. J. Water Environ. Nanotechnol. 2018, 3, 337-347.

81. Meashi, D.; Sharma, P.; Sharma, A.K. Bio-functionalized Gold Nanoparticles: A Potent Probe for Profound Antibacterial Efficiency through Drug Delivery System. Asian J. Biol. Life Sci. 2020, 9, 42-50.

82. Ochi, M.; Watanabe, M.; Miura, I.; Taniguchi, M.; Tokoroyama, T. Amijiol; isoamijiol; and 14-deoxyamijiol; three new diterpenoids from the brown seaweed Dictyota linearis. Chem. Lett. 1980, 9, 1229-1232. [CrossRef]

83. Ochi, M.; Asao, K.; Kotsuki, H.; Miura, I.; Shibata, K. Amijitrienol and 14-deoxyisoamijiol, two new diterpenoids from the brown seaward Dictyota linearis. Bull. Chem. Soc. Jpn. 1986, 59, 661-662. [CrossRef]

84. Crews, P.; Klein, T.E.; Hogue, E.R.; Myers, B.L. Tricyclic diterpenes from the brown marine algae Dictyota divaricata and Dictyota linearis. J. Org. Chem. 1982, 47, 811-815. [CrossRef]

85. Siamopoulou, P.; Bimplakis, A.; Iliopoulou, D.; Vagias, C.; Cos, P. Diterpenes from the brown algae Dictyota dichotoma and Dictyota linearis. Phytochemistry 2004, 65, 2025-2030. [CrossRef] [PubMed]

86. Wright, A.D.; König, G.M.; Sticher, O. New and highly oxidised hydroazulenoid diterpenes from the tropical marine brown alga Dictyota volubilis. Tetrahedron 1993, 49, 571-580. [CrossRef]

87. König, G.M.; Wright, A.D.; Sticher, O.; Rüegger, H. Four New Hydroazulenoid Diterpenes from the Tropical Marine Brown Alga Dictyota volubilis. Planta Med. 1993, 59, 174-178. [CrossRef]

88. Generalić Mekinić, I.; Šimat, V.; Botić, V.; Crnjac, A.; Smoljo, M.; Soldo, B.; Ljubenkov, I.; Čagalj, M.; Skroza, D. Bioactive Phenolic Metabolites from Adriatic Brown Algae Dictyota dichotoma and Padina pavonica (Dictyotaceae). Foods 2021, 10, 1187. [CrossRef]

89. El-Katony, T.M.; Deyab, M.A.; El-Adl, M.F.; Ward, F.M.E.-N. Extracts of the Brown Alga Dictyota dichotoma (Hudson) J.V. Lamouroux Alleviate Salt Stress in Rice (Oryza sativa L.) During Germination. J. Plant Growth Regul. 2021, 40, 986-999. [CrossRef]

90. Rachel, D.; Thangaraju, N. Phytochemical screening and comparative analysis of antimicrobial activity of selected species of brown seaweeds from Gulf of Mannar, Tamil Nadu, India. J. Mod. Biotechnol. 2015, 5, 1-7.

91. Shameel, M.; Shaikh, W.; Khan, R. Comparative fatty acid composition of five species of Dictyota (Phaeophyta). Bot. Mar. 1991, 34, 425-428. [CrossRef]

92. Ktari, L.; Ismail-Ben Ali, A.; Ben Redjem, Y.; Langar, H.; El Bour, M. Antifouling activity and chemical investigation of the brown alga Dictyota fasciola (Dictyotales) from Tunisian coast. Cah. Biol. Mar. 2010, 51, 109-115.

93. Vanaltena, I.; Mcgivern, J. New Spatane-Derived Diterpenoids from the Australian Brown Alga Dictyota fenestrata. Aust. J. Chem. 1992, 45, 541-551. [CrossRef]

94. Stephens, P.R.S.; Cirne-Santos, C.C.; de Souza Barros, C.; Teixeira, V.L.; Carneiro, L.A.D.; Amorim, L.d.S.C.; Ocampo, J.S.P.; Castello-Branco, L.R.R.; de Palmer Paixão, I.C.N. Diterpene from marine brown alga Dictyota friabilis as a potential microbicide against HIV-1 in tissue explants. J Appl. Phycol. 2017, 29, 775-780. [CrossRef]

95. Robertson, K.J.; Fenical, W. Pachydictyol-A epoxide, a new diterpene from the brown seaweed Dictyota flabellata. Phytochemistry 1977, 16, 1071-1073. [CrossRef]

96. Finer, J.; Clardy, J.; Fenical, W.; Minale, L.; Riccio, R.; Battaile, J.; Kirkup, M.; Moore, R.E. Structures of dictyodial and dictyolactone, unusual marine diterpenoids. J. Org. Chem. 1979, 44, 2044-2047. [CrossRef]

97. Tenorio-Rodríguez, P.; Méndez-Rodrìguez, L.; Serviere-Zaragoza, E.; OHara, T.; Zenteno-Savín, T. Antioxidant substances and trace element content in macroalgae from a subtropical lagoon in the West Coast of the Baja California Peninsula. Vitam. Trace Elem. 2013, 2, 1000108 .

98. Dunlop, R.; Ghisalberti, E.; Jefferies, P.; Skelton, B.; White, A. Structure of a New Dolastane Diterpene from Dictyota furcellata. Aust. J. Chem. 1989, 42, 315-319. [CrossRef]

99. De-Paula, J.C.; Cavalcanti, D.N.; Yoneshigue-Valentin, Y.; Teixeira, V.L. Diterpenes from marine brown alga Dictyota guineensis (Dictyotaceae, Phaeophyceae). Rev. Bras. Farmacogn. 2012, 22, 736-740. [CrossRef]

100. Shaikh, W.; Shameel, M.; Ahmad, V.U. Phycochemical studies on sterols from three brown seaweeds of northern Arabian Sea. Pak. J. Mar. Sci. 1995, 4, 107-113.

101. Ayesha, H.; Sultana, V.; Ara, J.; Ehteshamul-Haque, S. In vitro cytotoxicity of seaweeds from Karachi coast on brine shrimp. Pak. J. Bot. 2010, 42, 3555-3560.

102. Sun, H.H.; Fenical, W. Hydroxydilophol, a new monocyclic diterpenoid from the brown alga Dictyota masonii. J. Org. Chem. 1979, 44, 1354-1356. [CrossRef]

103. do Nascimento Ávila, F.; da Silva Souza, L.G.; de Macedo Carneiro, P.B.; Santos, F.A.; Sasahara, G.L.; Marinho Filho, J.D.B.; Araújo, A.J.; Barros, A.B.; Vieira Monteiro, N.D.K.; Silveira, E.R.; et al. Anti-inflammatory diterpenoids from the Brazilian alga Dictyota menstrualis. Algal Res. 2019, 44, 101695. [CrossRef] 
104. Pereira, H.; Leão-Ferreira, L.; Moussatché, N.; Teixeira, V.; Cavalcanti, D.; Costa, L.; Diaz, R.; Frugulhetti, I. Antiviral activity of diterpenes isolated from the Brazilian marine alga Dictyota menstrualis against human immunodeficiency virus type 1 (HIV-1). Antivir. Res. 2004, 64, 69-76. [CrossRef]

105. De Andrade Moura, L.; Marqui de Almeida, A.C.; Domingos, T.F.S.; Ortiz-Ramirez, F.; Cavalcanti, D.N.; Teixeira, V.L.; Fuly, A.L. Antiplatelet and anticoagulant effects of diterpenes isolated from the marine alga, Dictyota menstrualis. Mar. Drugs 2014, 12, 2471-2484. [CrossRef]

106. Abrantes, J.L.; Barbosa, J.; Cavalcanti, D.; Pereira, R.C.; Fontes, C.L.F.; Teixeira, V.L.; Souza, T.L.M.; Paixão, I.C. The effects of the diterpenes isolated from the Brazilian brown algae Dictyota pfaffii and Dictyota menstrualis against the herpes simplex type-1 replicative cycle. Planta Med. 2010, 76, 339-344. [CrossRef]

107. Gomes, D.L.; Telles, C.B.S.; Costa, M.S.S.P.; Almeida-Lima, J.; Costa, L.S.; Keesen, T.S.L.; Rocha, H.A.O. Methanolic extracts from brown seaweeds Dictyota cilliolata and Dictyota menstrualis induce apoptosis in human cervical adenocarcinoma HeLa cells. Molecules 2015, 20, 6573-6591. [CrossRef]

108. Albuquerque, I.R.L.; Queiroz, K.C.S.; Alves, L.G.; Santos, E.A.D.; Leite, E.L.; Rocha, H.A.O. Heterofucans from Dictyota menstrualis have anticoagulant activity. Braz. J. Med. Biol. Res. 2004, 37, 167-171. [CrossRef]

109. Albuquerque, I.R.; Cordeiro, S.L.; Gomes, D.L.; Dreyfuss, J.L.; Filgueira, L.G.; Leite, E.L.; Nader, H.B.; Rocha, H.A. Evaluation of anti-nociceptive and anti-inflammatory activities of a heterofucan from Dictyota menstrualis. Mar. Drugs 2013, 11, 2722-2740. [CrossRef]

110. Cirne-Santos, C.C.; Barros, C.; Gomes, M.W.L.; Gomes, R.; Cavalcanti, D.N.; Obando, J.M.C.; Ramos, C.J.B.; Villaça, R.C.; Teixeira, V.L.; Paixão, I.C.N.D.P. In vitro antiviral activity against Zika virus from a natural product of the Brazilian brown seaweed Dictyota menstrualis. Nat. Prod. Commun. 2019, 14, 1934578X19859128. [CrossRef]

111. Fernandes-Negreiros, M.M.; Araújo Machado, R.I.; Bezerra, F.L.; Nunes Melo, M.C.; Alves, M.G.C.F.; Alves Filgueira, L.G.; Morgano, M.A.; Trindade, E.S.; Costa, L.S.; Rocha, H.A.O. Antibacterial, antiproliferative, and immunomodulatory activity of silver nanoparticles synthesized with fucans from the alga Dictyota mertensii. Nanomaterials 2018, 8, 6. [CrossRef]

112. Nunes Pinheiro, A.D.; Pereira Lopes-Filho, E.A.; De-Paula, J.C.; Pereira Netto, A.D.; Teixeira, V.L. Diterpenes from the brown alga Dictyota mertensii. Biochem. Syst. Ecol. 2019, 86, 103926. [CrossRef]

113. Rubiano-Buitrago, P.; Duque, F.; Puyana, M.; Ramos, F.A.; Castellanos, L. Bacterial biofilm inhibitor diterpenes from Dictyota pinnatifida collected from the Colombian Caribbean. Phytochem. Lett. 2019, 30, 74-80. [CrossRef]

114. Zhao, M.; Cheng, S.; Yuan, W.; Dong, J.; Huang, K.; Sun, Z.; Yan, P. Further New Xenicanes from a Chinese Collection of the brown Alga Dictyota plectens. Chem. Pharm. Bull. 2015, 63, 1081-1086. [CrossRef]

115. Cheng, S.; Zhao, M.; Sun, Z.; Yuan, W.; Zhang, S.; Xiang, Z.; Cai, Y.; Dong, J.; Huang, K.; Yan, P. Diterpenes from a Chinese collection of the brown alga Dictyota plectens. J. Nat. Prod. 2014, 77, 2685-2693. [CrossRef]

116. Queiroz, T.M.; Machado, N.T.; Furtado, F.F.; Oliveira-Filho, A.A.; Alustau, M.C.; Figueiredo, C.S.; Miranda, G.E.; Barbosa-Filho, J.M.; Braga, V.A.; Medeiros, I.A. Vasorelaxation, induced by Dictyota pulchella (Dictyotaceae), a brown alga, is mediated via inhibition of calcium influx in rats. Mar. Drugs 2011, 9, 2075-2088. [CrossRef]

117. McDermid, K.J.; Stuercke, B. Nutritional composition of edible Hawaiian seaweeds. J. Appl. Phycol. 2003, 15, 513-524. [CrossRef]

118. Tanaka, J.; Higa, T. Hydroxydictyodial, a new antifeedant diterpene from the brown alga Dictyota spinulosa. Chem. Lett. 1984, 13, 231-232. [CrossRef]

119. Chiboub, O.; Sifaoui, I.; Lorenzo-Morales, J.; Abderrabba, M.; Mejri, M.; Fernández, J.J.; Piñero, J.E.; Díaz-Marrero, A.R. Spiralyde A, an antikinetoplastid dolabellane from the brown alga Dictyota spiralis. Mar. Drugs 2019, 17, 192. [CrossRef] [PubMed]

120. Othmani, A.; Bouzidi, N.; Viano, Y.; Alliche, Z.; Seridi, H.; Blache, Y.; El Hattab, M.; Briand, J.-F.; Culioli, G. Anti-microfouling properties of compounds isolated from several Mediterranean Dictyota spp. J. Appl. Phycol. 2014, 26, 1573-1584. [CrossRef]

121. Viano, Y.; Bonhomme, D.; Ortalo-Magné, A.; Thomas, O.P.; Hattab, M.E.; Piovetti, L.; Blache, Y.; Culioli, G. Dictyotadimer A, a new dissymmetric bis-diterpene from a brown alga of the genus Dictyota. Tetrahedron Lett. 2011, 52, 1031-1035. [CrossRef]

122. Guella, G.; Ndiaye, I.; Chiasera, G.; Pietra, F. Joalin, the first nitrogen-containing xenicane diterpene isolated from a brown seaweed collected off the Senegalese coast. J. Chem. Soc. Perkin Trans. I 1993, 10, 1545-1546. [CrossRef]

123. Tringali, C.; Oriente, G.; Piattelli, M.; Nicolosi, G. Two minor dolabellane diterpenoid constituents from a Dictyota species. J. Nat. Prod. 1985, 48, 484-485. [CrossRef]

124. Vazquez, J.T.; Chang, M.; Nakanishi, K.; Manta, E.; Perez, C.; Martin, J.D. Structure of hydroazulenoid diterpenes from a marine alga and their absolute configuration based on circular dichroism. J. Org. Chem. 1988, 53, 4797-4800. [CrossRef]

125. Gonzalez, A.G.; Martin, J.D.; Gonzalez, B.; Ravelo, J.L.; Perez, C.; Rafii, S.; Clardy, J. A new diterpene with a novel carbon skeleton from a marine alga. J. Chem. Soc. Chem. Commun. 1984, 669-670. [CrossRef]

126. Chiboub, O.; Sifaoui, I.; Abderrabba, M.; Mejri, M.; Fernández, J.J.; Díaz-Marrero, A.R.; Lorenzo-Morales, J.; Piñero, J.E. Apoptosislike cell death upon kinetoplastid induction by compounds isolated from the brown algae Dictyota spiralis. Parasite Vectors 2021 14, 198. [CrossRef] [PubMed]

127. Wu, J.; Xi, Y.; Li, G.; Zheng, Y.; Wang, Z.; Wang, J.; Fang, C.; Sun, Z.; Hu, L.; Jiang, W.; et al. Hydroazulene diterpenes from a Dictyota brown alga and their antioxidant and neuroprotective effects against cerebral ischemia-reperfusion injury. J. Nat. Prod. 2021, 84, 1306-1315. [CrossRef] 